\title{
Therapeutic Monoclonal Antibodies and Antibody Products: Current Practices and Development in Multiple Myeloma
}

\author{
Francesca Bonello, Roberto Mina, Mario Boccadoro and Francesca Gay *(D) \\ Myeloma Unit, Division of Hematology, University of Torino, Azienda Ospedaliero-Universitaria Città della \\ Salute e della Scienza di Torino, 10126 Torino, Italy; francesca.bonello@edu.unito.it (F.B.); \\ roberto.mina.rm@gmail.com (R.M.); mario.boccadoro@unito.it (M.B.) \\ * Correspondence: fgay@cittadellasalute.to.it; Tel.: +39-011-6333-4279/4301; Fax: +39-011-6333-4187
}

Received: 8 November 2019; Accepted: 16 December 2019; Published: 19 December 2019

\begin{abstract}
Immunotherapy is the latest innovation for the treatment of multiple myeloma (MM). Monoclonal antibodies (mAbs) entered the clinical practice and are under evaluation in clinical trials. MAbs can target highly selective and specific antigens on the cell surface of MM cells causing cell death (CD38 and CS1), convey specific cytotoxic drugs (antibody-drug conjugates), remove the breaks of the immune system (programmed death 1 (PD-1) and PD-ligand 1/2 (L1/L2) axis), or boost it against myeloma cells (bi-specific mAbs and T cell engagers). Two mAbs have been approved for the treatment of MM: the anti-CD38 daratumumab for newly-diagnosed and relapsed/refractory patients and the anti-CS1 elotuzumab in the relapse setting. These compounds are under investigation in clinical trials to explore their synergy with other anti-MM regimens, both in the front-line and relapse settings. Other antibodies targeting various antigens are under evaluation. B cell maturation antigens (BCMAs), selectively expressed on plasma cells, emerged as a promising target and several compounds targeting it have been developed. Encouraging results have been reported with antibody drug conjugates (e.g., GSK2857916) and bispecific T cell engagers (BiTEs ${ }^{\circledR}$ ), including AMG420, which re-directs T cell-mediated cytotoxicity against MM cells. Here, we present an overview on mAbs currently approved for the treatment of MM and promising compounds under investigation.
\end{abstract}

Keywords: multiple myeloma (MM); immunotherapy; monoclonal antibodies (mAbs); antibody products; B cell maturation antigens (BCMAs); bispecific T cell engagers (BiTEs ${ }^{\circledR}$ )

\section{Introduction}

Multiple myeloma (MM) is a hematologic malignancy characterized by a clonal expansion of aberrant plasma cells in the bone marrow inducing bone lesions, anemia, renal insufficiency and hypercalcemia. In the last two decades, the treatment armamentarium of effective anti-myeloma drugs, used both at diagnosis and at relapse, has been significantly expanded with various compounds of different drug-classes. However, despite the availability of several treatment options, MM still remains an incurable disease whose natural history is characterized by phases of disease remission followed by relapses. The remission duration tends to progressively decrease at every subsequent relapse and MM inevitably becomes refractory to all available agents. Therefore, even if the survival of MM patients, both young and elderly, has steadily increased over time, to date, roughly $50 \%$ of patients are alive at 5 years after diagnosis [1-3].

With the introduction of effective novel agent combinations, based on immunomodulatory agents (IMiDs) and proteasome inhibitors (PIs), the treatment goal for first-line therapies is now the achievement of minimal residual disease (MRD) negativity [4], which is currently reported in 
$50-80 \%$ of transplant-eligible [5-8] and in $15-30 \%$ of transplant-ineligible patients [9-11]. A large meta-analysis demonstrated that reaching MRD negativity (though with some variability in terms of methods and cut-offs adopted) significantly prolonged progression-free survival (PFS) and overall survival (OS) as compared to a MRD-positive status [12]. For this reason, efforts should be made to improve the effectiveness of first-line therapies in inducing deep and durable responses. Regardless of the effectiveness of newer combinations available at diagnosis, the prognosis of high-risk patients (e.g., patients with unfavorable genetics or molecular abnormalities, International Staging System (ISS) stage III, extramedullary disease, or those who experience an early relapse after first-line therapies) is dismal compared to that of standard-risk patients. This evidence prompts the development of different strategies and the adoption of newer drugs in this population, currently representing an unmet medical need.

Furthermore, despite the depth of response obtained with first-line therapies and the duration of the remission, relapse is inevitable in almost all patients with MM, who progressively become refractory to all approved drugs, particularly to IMiDs and PIs. The development of compounds with different mechanisms of action, aiming at synergizing with currently used agents and overcoming drug-induced resistance, is therefore a priority.

Immunotherapy, either passive-with monoclonal antibodies (mAbs) or cellular products directed against neoplastic cells-or active-when the patient's immune system is stimulated to mount an immune response against tumor cells-represents a pivotal strategy for the treatment of both solid and hematologic malignancies.

MAbs have entered the clinical practice for the treatment of MM [13]. They are selective compounds targeting surface antigens that are highly expressed on aberrant plasma cells and not (or at low density) on normal tissues, thus promoting on-target activity while limiting off-target toxicity. MAbs elicit their therapeutic actions through different mechanisms, including a direct cytotoxicity on the neoplastic cell and immune-mediated mechanisms such as antibody-dependent cell-mediated cytotoxicity (ADCC), antibody-dependent cell-mediated phagocytosis (ADCP) and complement-dependent cytotoxicity (CDC). Monoclonal antibodies can also be exploited to directly target the myeloma cell while conveying a cytotoxic agent, as in the case of antibody-drug conjugates (ADCs), or to engage and activate $\mathrm{T}$ cells against the myeloma cell as with bispecific $T$ cell engagers.

Several potential targets have been identified on the myeloma cells and likewise constructs have been designed and tested in MM patients, some of them having already entered the clinical practice.

This review focuses on the strength and controversies of the current treatment strategies exploiting mAbs in MM, as well as on newer experimental immunotherapeutic approaches such as ADCs and bispecific T-cell engagers (BiTEs $\left.{ }^{\circledR}\right)$.

\section{Monoclonal Antibodies}

\subsection{Anti-CD38 Monoclonal Antibodies}

\subsubsection{Rationale}

CD38 is a transmembrane type II glycoprotein that is highly expressed on normal plasma cells as well as on MM cells [14]. CD38 is also present at lower levels on normal lymphoid and myeloid cells, on red blood cells, as well as on solid tissues such as muscle cells (especially in the airway system), epithelial cells in the prostate and pancreatic beta cells. CD38 acts as a receptor, as an adhesion molecule, and as an ectoenzyme [15-17].

Anti-CD38 mAbs elicit their action targeting CD38+ MM cells and inducing effector mechanisms such as ADCC (which relies mainly on natural killer [NK] cells), ADCP, and CDC [18-21]. An in vitro comparison between the different anti-CD38 molecules showed that ADCC was equally induced by all of them, whereas daratumumab induced the highest CDC at low concentration and ADCP [22]. Alongside immune-mediated cytotoxicity, anti-CD38 mAbs have an immunomodulatory activity that relies on the modulation of immune cells. Myeloid-derived suppressor cells (MDSC), regulatory B cells 
(Bregs, which promote tumor growth and immune escape), as well as a subset of regulatory $\mathrm{T}$ cells (Tregs) express CD38, and their levels are reduced after daratumumab exposure. Conversely, daratumumab results in significant expansion of CD8+ cytotoxic and CD4+ helper T cells, likely following the depletion of regulatory cells. Remarkably, expanded effector $\mathrm{T}$ cells also show increased killing capacity due to augmented levels of granzyme B, which activates caspases and triggers cell apoptosis [23-25]. In addition, among the activities promoted by $\mathrm{CD} 38$, there is a nicotinamide adenine dinucleotide (NAD)-ase activity, which results in reduced levels of NAD+ in T cells, responsible for the loss of their effector functions (exhausted T cells). In murine models, anti-CD38 mAbs administration induced higher levels of NAD+ in T effector cells, thus enhancing their antitumor activity [23]. The main mechanisms of action of anti-CD38 monoclonal antibodies are summarized in Figure 1.

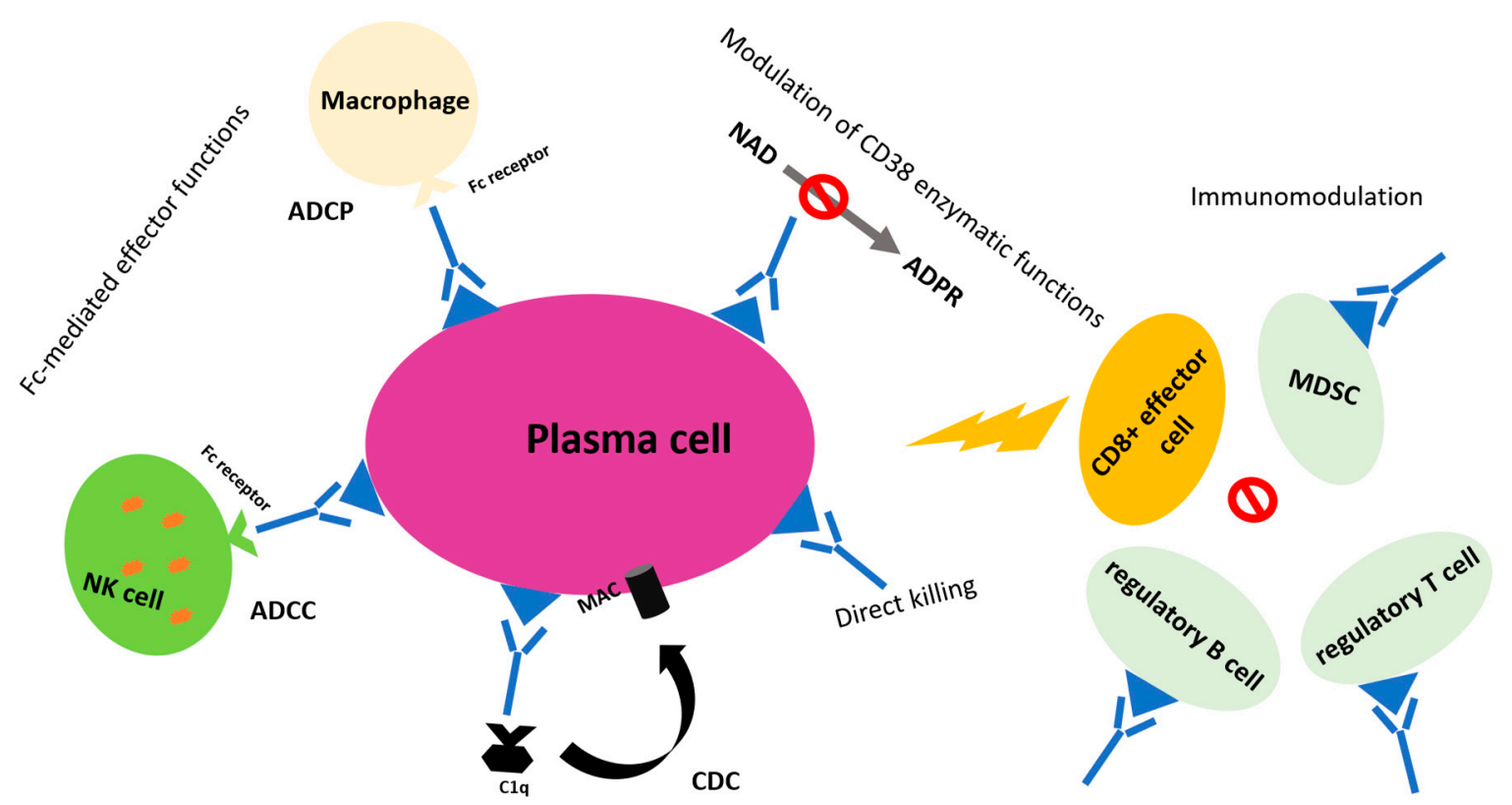

Figure 1. Main mechanisms of action of anti-CD38 monoclonal antibodies. Abbreviations: MDSC, myeloid-derived suppressor cell; ADCC, antibody-dependent cell-mediated cytotoxicity; CDC, complement-dependent cytotoxicity; NAD, nicotinamide adenine dinucleotide; ADPR, adenosine ribose; MAC, membrane attack complex.

In vitro studies showed a marked synergism between anti-CD38 mAbs (daratumumab, isatuximab and MOR202) and IMiDs (lenalidomide and pomalidomide), mainly owing to an enhanced NK activity elicited by IMiDs that increases both number and activity of NK cells and consequently ADCC, as well as the cytotoxic activity of macrophages, thus stimulating ADCP [26]. This evidence prompted the investigation of the in vivo effect of the addition of anti-CD38 mAbs to IMiD-based combinations. Anti-CD38 mAbs also show an additive effect with PIs [27], although the exact mechanisms are less clear.

\subsubsection{Clinical Development}

\section{Daratumumab}

Daratumumab was the first fully human anti-CD38 mAb to be tested in clinical trials. Results of the main clinical trials are summarized in Table 1. 
Table 1. Results of the main clinical trials with anti-CD38 monoclonal antibodies daratumumab and isatuximab.

\begin{tabular}{|c|c|c|c|c|c|c|c|}
\hline Study & Phase & $\begin{array}{c}\text { Number } \\
\text { of Patients }\end{array}$ & $\begin{array}{l}\text { Median } \\
\text { Previous } \\
\text { Line }\end{array}$ & Regimen & ORR & $\begin{array}{c}\text { Median } \\
\text { PFS } \\
\text { (Months) }\end{array}$ & $\begin{array}{c}\text { Median } \\
\text { OS } \\
\text { (Months) }\end{array}$ \\
\hline \multicolumn{8}{|c|}{ RELAPSED PATIENTS } \\
\hline $\begin{array}{c}\text { GEN501 + } \\
\text { SIRIUS } \\
\text { POOLED [28] }\end{array}$ & II & 148 & 5 & $\begin{array}{c}\text { Daratumumab } \\
\text { single agent }\end{array}$ & $31.1 \%$ & 4 & 20.1 \\
\hline POLLUX [29] & III & 569 & 1 & Dara-Rd vs. Rd & $\begin{array}{c}92.9 \% \text { vs. } \\
76.4 \%\end{array}$ & $\begin{array}{l}\text { NR vs. } \\
17.5\end{array}$ & $\begin{array}{c}1 \text { 1-year OS } \\
92.1 \% \text { vs. } \\
86.8 \%\end{array}$ \\
\hline CASTOR $[30,31]$ & III & 498 & 2 & Dara-Vd vs. Vd & $\begin{array}{c}83.8 \% \text { vs. } \\
63.2 \%\end{array}$ & 16.7 vs. 7.1 & NA \\
\hline $\begin{array}{c}\text { NCT01998971 } \\
{[32]}\end{array}$ & II & 103 & 4 & Dara-Poma-dex & $60 \%$ & 8.8 & 17.5 \\
\hline $\begin{array}{c}\text { NCT01998971 } \\
\text { [33] }\end{array}$ & $\mathrm{Ib}$ & 85 & 2 & Dara-Kd & $84 \%$ & $\begin{array}{c}\text { 1-year PFS } \\
74 \%\end{array}$ & $\begin{array}{c}\text { 1-year OS } \\
82 \%\end{array}$ \\
\hline $\begin{array}{c}\text { NCT01749969 } \\
\text { [34] }\end{array}$ & $\mathrm{Ib}$ & 57 & 5 & Isa-Rd & $56 \%$ & 8.5 & NR \\
\hline $\begin{array}{c}\text { NCT02283775 } \\
\text { [35] }\end{array}$ & $\mathrm{Ib}$ & 45 & 3 & Isa-Pd & $62 \%$ & 17.6 & NR \\
\hline $\begin{array}{c}\text { NCT02332850 } \\
{[36]}\end{array}$ & $\mathrm{Ib}$ & 33 & 3 & Isa-Kd & $66 \%$ & NR & NR \\
\hline ICARIA [37] & III & 307 & 3 & Isa-Pd vs. Pd & $\begin{array}{c}60 \% \text { vs. } \\
35 \%\end{array}$ & $\begin{array}{c}11.5 \mathrm{vs} . \\
6.5\end{array}$ & NA \\
\hline \multicolumn{8}{|c|}{ NEWLY DIAGNOSED PATIENTS } \\
\hline ALCYONE [11] & III & $706 \mathrm{TNE}$ & - & $\begin{array}{l}\text { Dara-VMP vs. } \\
\text { VMP }\end{array}$ & $\begin{array}{c}90.9 \% \text { vs. } \\
73.9 \%\end{array}$ & $\begin{array}{c}\text { NR vs. } \\
18.1\end{array}$ & NA \\
\hline MAIA [38] & III & $737 \mathrm{TNE}$ & - & Dara-Rd vs. Rd & $\begin{array}{c}92.9 \% \text { vs. } \\
81.3 \%\end{array}$ & $\begin{array}{l}\text { NR vs. } \\
31.9\end{array}$ & NA \\
\hline $\begin{array}{c}\text { CASSIOPEIA } \\
\text { [39] }\end{array}$ & III & $1085 \mathrm{TE}$ & - & $\begin{array}{l}\text { Dara-VTd vs. } \\
\text { VTd }\end{array}$ & $\begin{array}{l}\geq \text { CR } 39 \% \\
\text { vs. } 26 \%\end{array}$ & NA & NA \\
\hline GRIFFIN [40] & II & $207 \mathrm{TE}$ & - & $\begin{array}{c}\text { Dara-VRd vs } \\
\text { VRd }\end{array}$ & $\begin{array}{c}51.5 \% \text { vs. } \\
42.3 \%\end{array}$ & NA & NA \\
\hline
\end{tabular}

Abbreviations: ORR, overall response rate; PFS, progression-free survival; OS, overall survival; Dara, daratumumab; Isa, isatuximab; $\mathrm{V}$, bortezomib; $\mathrm{C}$, cyclophosphamide; $\mathrm{d}$, dex, dexamethasone; $\mathrm{T}$, thalidomide; $\mathrm{R}$, lenalidomide; $\mathrm{K}$, carfilzomib; Poma, pomalidomide; M, melphalan; P, prednisone; NR, not reached; NA, not yet available;

$\mathrm{TNE}$, transplant ineligible; TE, transplant eligible; CR, complete response.

In the phase I GEN501 study, which investigated different doses of daratumumab in relapsed/ refractory (RR)MM patients, the greatest activity was reported at the dose of $16 \mathrm{mg} / \mathrm{kg}$, at which $36 \%$ of patients achieved a partial response (PR) or better. These results were confirmed by the phase II SIRIUS trial, which reported a $29 \%$ overall response rate (ORR) in heavily pretreated patients, resulting into median PFS and OS of 3.7 and 17.5 months, respectively [41]. These results led to the approval, by both the Food and Drug Administration (FDA) and the European Medicines Agency (EMA), of daratumumab as single agent for RRMM patients with 3 prior lines of therapy including a PI and an IMiD.

The synergism showed in vitro by daratumumab and lenalidomide was first translated into a marked in vivo activity of the 3-drug combination daratumumab-lenalidomide-dexamethasone (Dara-Rd) observed in RRMM patients enrolled in the phase II GEN503 study and then confirmed by the phase III POLLUX study. In the POLLUX trial, 569 RRMM patients were randomized to receive standard lenalidomide-dexamethasone (Rd) versus Dara-Rd until disease progression or intolerance [29]. ORR was higher in the triplet arm (93\% vs. $76 \%)$ as well as the rate of patients achieving minimal residual disease (MRD) negativity ( $26 \%$ vs. $6 \%$ of patients, threshold $\left.10^{-5}\right)$. Median PFS was not reached (NR) versus 
17.5 months (hazard ratio [HR] 0.41, $p<0.001$ ) in the Dara-Rd versus Rd arms; this benefit was also consistent in patients with high-risk cytogenetics (HR 0.53, $p=0.09$ ) [42]. Of notice, the addition of daratumumab to $\mathrm{Rd}$ did not significantly increase the rates of grade 3-4 toxicities, with the exception of neutropenia ( $54 \%$ vs. $39 \%$ ) and infections ( $28.3 \%$ vs. $22.8 \%$ ). These data supported the approval of Dara-Rd for the treatment of MM patients who had previously received at least 1 line of therapy.

Daratumumab was then evaluated with pomalidomide and dexamethasone (Dara-Pd). In a preliminary phase II trial, this 3-drug regimen showed, in a heavily pretreated population (the median number of prior therapies was 4$)$, ORR (60\%) and median PFS (8.8 months) that compared favorably with those of Pd alone (ORR 31\%, median PFS 3.8 months) despite the limitations of a cross-trial comparison $[32,43]$. Following the results of this study, the triplet Dara-Pd received accelerated approval by the FDA for RRMM patients who previously received both an IMiD and a PI. This combination is appealing considering that, in the near future, the majority of newly diagnosed (ND)MM patients will become refractory to continuous lenalidomide after their first line of therapy. Definitive results will come from the phase III trial APOLLO (NCT03180736) comparing Dara-Pd vs. Pd in RRMM patients.

Daratumumab has also been associated with PIs. The phase III CASTOR trial compared bortezomibdexamethasone (Vd) administered for 8 cycles to daratumumab-Vd (Dara-Vd) for 8 cycles, followed by monthly daratumumab until progression in RRMM patients [30]. The addition of daratumumab resulted in higher ORR ( $83 \%$ vs. $63 \%)$ and MRD negativity rate $\left(12 \%\right.$ vs. $2 \%$, threshold $\left.10^{-5}\right)$, and in prolonged PFS (median, 16.7 vs. 7.1 months; HR 0.31; $p<0.0001$ ) [31]. Importantly, the MRD negativity rate continued to increase over time for patients receiving Dara- $\mathrm{Vd}$ as compared to those receiving $\mathrm{Vd}$, thus highlighting the benefit of continuous treatment with daratumumab. The PFS advantage was also consistent for patients previously exposed to bortezomib (HR 0.35, $p<0.001$ ) and for patients with high-risk cytogenetic features detected by fluorescence in situ hybridization (FISH, HR 0.45, $p=0.05$ ). The triplet Dara-Vd is currently approved by the FDA and EMA for RRMM patients.

A phase Ib study with carfilzomib-dexamethasone-daratumumab (KdD) induced an objective response in $84 \%$ of RRMM patients after both lenalidomide and bortezomib [33]. It was recently announced that the phase III CANDOR study (NCT03158688) comparing Kd to KdD met its primary endpoint, with a $37 \%$ reduction in the risk of progression or death (HR $0.63,95 \%$ CI $0.464-0.854$, $p=0.0014$ ) in patients receiving daratumumab [44].

Because CD38 expression is higher in the early stages of the disease, and mAbs greatly rely on the immune system to exploit their anti-MM activity, it seems reasonable to expect that moving daratumumab to the first-line setting, when the immune-system of a treatment-naïve patient is less compromised, could increase its efficacy. In older patients with newly diagnosed (ND)MM, daratumumab plus bortezomib-melphalan-prednisone (Dara-VMP), followed by daratumumab maintenance, significantly increased the MRD negativity rate as compared to the standard of care VMP $\left(22 \%\right.$ vs. $6 \%, p<0.001$, threshold $\left.10^{-5}\right)$, ultimately prolonging the median PFS (NR after a median follow-up of 17 months vs. 18.1 months, HR 0.50, $p<0.001$ ) [11]. Highlighting the role of continuous treatment, a substantial benefit in PFS was detected during the maintenance phase when a lower rate of relapses was observed in patients receiving daratumumab compared with observation (sustained response after 18 months: $77 \%$ vs. $60 \%$ ). This evidence supports the benefit of continuous therapy with daratumumab, which allows better disease control over time compared to fixed duration treatment. A longer follow-up is needed to detect an OS benefit. Dara-VMP has recently been approved by both the FDA and EMA, thus becoming one of the standards of care for transplant-ineligible patients. Impressive results in terms of higher MRD negativity rates $(24.2 \%$ vs. $7.3 \%$, respectively; $p<0.001$, threshold $10^{-5}$ ) and reduced risk of progression or death (median NR vs. 32 months after a median follow-up of 28 months, HR 0.56, $p<0.001$ ) were observed when Dara-Rd was compared to Rd in NDMM patients not suitable for autologous stem-cell transplantation (ASCT; MAIA study [38]). In both Dara-VMP and Dara-Rd regimens, the addition of daratumumab did not negatively affect the safety profiles of VMP and Rd, despite a higher rate of grade 3-4 infections being reported in both studies in patients receiving daratumumab (Dara-VMP 23.1\% vs. VMP 14.7\%; Dara-Rd 32\% vs. Rd 
$23 \%$ ); also, the frequency of grade $3-4$ neutropenia was higher in patients receiving daratumumab in the MAIA study ( $50 \%$ vs. $35 \%)$.

Daratumumab has also been incorporated in the induction, consolidation, and maintenance approach in combination with standard triplets such as bortezomib-thalidomide-dexamethasone (VTd) and bortezomib-lenalidomide-dexamethasone (VRd) as initial treatment for NDMM patients eligible for high-dose melphalan and ASCT.

The phase III CASSIOPEIA trial randomized 1085 transplant-eligible patients to VTd with or without daratumumab as induction and consolidation, followed by daratumumab maintenance or no maintenance. After the consolidation phase, the proportion of MRD-negative patients was higher in the Dara-VTd group than in the VTd group ( $64 \%$ vs. $44 \%, p<0.001$, threshold $\left.10^{-5}\right)$. This translated into a significantly reduced risk of progression or death in the Dara-VTd arm as compared to the control group (HR for PFS 0.47, $p<0.001$ ) [39]. The higher MRD negativity rate reported with daratumumab was also confirmed in ISS-III and high-risk FISH patients ( $64 \%$ vs. $46 \%, p=0.01 ; 60 \%$ vs. $40 \%, p=0.06$, respectively), with a trend towards PFS improvement with daratumumab (HR 0.66, 95\% CI 0.31-1.39; HR $0.67,95 \%$ CI $0.35-1.30$, respectively) in these subsets of patients that traditionally represent unmet clinical needs [45]. Mobilization and stem collection after a more intensified induction including daratumumab were adequate. Although patients in the Dara-VTd arm required the use of plerixafor more frequently ( $22 \%$ vs. $8 \%$ ) and collected less CD34+ cells (median $6.3 \times 10^{6} / \mathrm{kg}$ vs. $8 \times 10^{6} / \mathrm{kg}$ ), successful ASCT and hematopoietic reconstitution were not affected. Data on maintenance are eagerly awaited. Following the results of the CASSIOPEIA trial, in September 2019, the FDA has approved frontline Dara-VTd as induction for transplant-eligible patients. VRd \pm daratumumab as induction and post-ASCT consolidation followed by lenalidomide \pm daratumumab maintenance is being compared in the ongoing phase II GRIFFIN trial [40]. The quadruplet significantly improved the MRD negativity rate (threshold $\left.10^{-5}\right)$ at the end of consolidation, as compared to VRd (47.9\% vs. $17.9 \%$, HR 0.23 , $p<0.001)$. In both trials, patients treated with daratumumab experienced no significant increase in grade 3-4 non-hematologic adverse events (AEs). Data on maintenance will shed light on the role of daratumumab maintenance, either alone or in combination with lenalidomide.

Other ongoing phase II/III trials evaluating front-line daratumumab in ASCT-eligible patients include the EMN17/PERSEUS trial, which explores the addition of daratumumab to VRd as induction and consolidation and to lenalidomide as maintenance treatment, and the EMN18 study, which compares induction and consolidation with daratumumab-bortezomib-cyclophosphamidedexamethasone (Dara-VCd) to standard VTd followed by ASCT and maintenance with ixazomib \pm daratumumab [46]. The main ongoing trials are summarized in Table 2.

Table 2. Main ongoing trials involving daratumumab and isatuximab in multiple myeloma patients.

\begin{tabular}{cccc}
\hline Study & Setting & Phase & Study Design \\
\hline DARATUMUMAB & \\
\hline & & Dara-VRd + \\
& & ASCT + \\
NCT03710603 [46] & NDMM & & Dara-VRd consolidation + \\
& TE & III & Dara-R maintenance \\
& $(690$ pts $)$ & & vs. \\
& & VRd + \\
& & ASCT + \\
& & VRd consolidation + \\
& & R maintenance \\
\hline
\end{tabular}


Table 2. Cont.

\begin{tabular}{|c|c|c|c|}
\hline NCT03896737 & $\begin{array}{l}\text { NDMM } \\
\text { TE } \\
(\approx 400 \text { pts })\end{array}$ & II & $\begin{array}{c}\text { Dara-VCd + } \\
\text { double ASCT }+ \\
\text { Dara-VCd consolidation } \\
\text { vs. } \\
\text { VTd }+ \\
\text { double ASCT + } \\
\text { VTd consolidation } \\
\text { Second randomization: } \\
\text { Ixa maintenance } \\
\text { vs. } \\
\text { Ixa-Dara }\end{array}$ \\
\hline NCT03180736 & $\begin{array}{l}\text { RRMM } \\
\text { (302 pts) }\end{array}$ & III & $\begin{array}{c}\text { Dara-Poma-dex } \\
\text { vs. } \\
\text { Poma-dex }\end{array}$ \\
\hline NCT03158688 & $\begin{array}{l}\text { RRMM } \\
\text { (466 pts) }\end{array}$ & III & $\begin{array}{c}\text { Dara-Kd } \\
\text { vs. } \\
\text { Kd }\end{array}$ \\
\hline \multicolumn{4}{|c|}{ ISATUXIMAB } \\
\hline NCT02513186 [47,48] & $\begin{array}{l}\text { NDMM } \\
\text { NTE } \\
\text { (88 pts) }\end{array}$ & $\mathrm{I} / \mathrm{II}$ & $\begin{array}{l}\text { Isa-VCd } \\
\text { vs. } \\
\text { Isa-VRd }\end{array}$ \\
\hline NCT03319667 [49] & $\begin{array}{l}\text { NDMM, NTE } \\
\quad(475 \text { pts })\end{array}$ & III & $\begin{array}{c}\text { Isa-VRd } \\
\text { vs. } \\
\text { VRd }\end{array}$ \\
\hline NCT03275285 & $\begin{array}{l}\text { RRMM } \\
\text { (302 pts) }\end{array}$ & III & $\begin{array}{c}\text { Isa-Kd } \\
\text { vs. } \\
\text { Kd }\end{array}$ \\
\hline NCT02990338 [50] & $\begin{array}{l}\text { RRMM } \\
\text { (300 pts) }\end{array}$ & III & $\begin{array}{c}\text { Isa-Poma-dex } \\
\text { vs. } \\
\text { Poma-dex }\end{array}$ \\
\hline
\end{tabular}

Abbreviations: pts, patients; NDMM, newly diagnosed multiple myeloma; RRMM, relapsed/refractory MM; Dara, daratumumab; Isa, isatuximab; ASCT, autologous stem-cell transplantation; TE, transplant eligible; NTE, transplant ineligible; Ixa, ixazomib; V, bortezomib; C, cyclophosphamide; d, dex, dexamethasone; T, thalidomide; $\mathrm{R}$, lenalidomide; K, carfilzomib; Poma, pomalidomide.

It is currently a matter of debate whether patients with smoldering (S)MM should receive therapy with the aim of preventing the progression to symptomatic MM and the associated morbidity. Two randomized trials demonstrated the benefit of lenalidomide, with or without dexamethasone, in delaying the time to progression to active $\mathrm{MM}$ versus observation; importantly, the longer follow-up of the Spanish trial allowed for the detection of an OS advantage for lenalidomide-treated patients [51]. In this setting, a highly targeted therapy with a good safety profile stands out as an ideal option. In the phase II CENTAURUS trial, single-agent daratumumab resulted in an ORR of 56\% in high-risk SMM patients, and median PFS was NR after a median follow-up of 26 months [52,53]. The randomized phase III AQUILA study is currently comparing daratumumab administered for 3 years versus standard observation in high-risk SMM (NCT03301220).

One of the limitations to the use of daratumumab is its long infusion time ( $3.5 \mathrm{~h})$. To deal with this issue, a shorter infusion schedule was tested-daratumumab was administered over a $90 \mathrm{~min}$ infusion at the usual dose $(16 \mathrm{mg} / \mathrm{kg}$ ) from the third infusion onward, without increasing the risk for infusion-related reactions (IRRs) or further short-term AEs [54]. A game changer in this setting will be the possibility of delivering daratumumab subcutaneously over a short period of time. The PAVO study explored subcutaneous daratumumab in combination with the recombinant human hyaluronidase $\mathrm{PH} 20$ enzyme (rHuPH20), which allowed for the reaching and maintaining of a high-serum concentration of 
the $\mathrm{mAb}$ [55]. At the end of phase $\mathrm{Ib}$ of the study, a flat dose of $1800 \mathrm{mg}$ was recommended on the basis of pharmacokinetics, safety (all-grade IRRs 25\%), and efficacy data (ORR 42\%).

Isatuximab

Isatuximab (SAR 650984) is an anti-CD38 immunoglobulin G (IgG)-k chimeric monoclonal antibody that, besides having the same mechanisms of action of daratumumab, holds a unique direct proapoptotic effect independent from the Fc cross-linking [56,57]. Results of the main clinical trials are summarized in Table 1.

Similarly to daratumumab, isatuximab showed a promising activity when administered as a single agent in heavily pre-treated MM patients [58] and has therefore been combined with different anti-MM compounds. A phase $\mathrm{Ib}$ trial combined isatuximab at different dose levels with Rd in heavily pretreated MM patients ( 5 median prior lines of therapy), of whom $68 \%$ had already received carfilzomib or pomalidomide and $82 \%$ were refractory to lenalidomide. ORR was $51 \%$ (and $52 \%$ in lenalidomide-refractory patients) and median PFS was 8.5 months. IRRs were the most common AEs related to isatuximab (56\% of patients, mainly of grades 1-2 and limited to first infusions) [34]. Another phase $\mathrm{Ib}$ trial combined isatuximab with $\mathrm{Pd}$ in relapsed patients (3 median prior lines of therapy) - the ORR was $62 \%$ and the median PFS was 17.6 months [35]. For both combinations, the selected dose of isatuximab was $10 \mathrm{mg} / \mathrm{kg}$ for 4 weekly doses and every 2 weeks thereafter. Of notice, preliminary results of a phase $\mathrm{Ib}$ trial in which isatuximab was combined to Kd showed a promising $66 \%$ ORR [36].

The ongoing phase III ICARIA trial (NCT02990338) is comparing the triplet isatuximabpomalidomide-dexamethasone (Isa-Pd) to $\mathrm{Pd}$ in $307 \mathrm{RRMM}$ patients who had received at least 2 previous lines of therapy (median lines: 3 in both groups). After a median follow-up of 11.6 months, a consistent benefit in terms of ORR $(60 \%$ vs. $35 \%, p<0.001)$ and PFS (median PFS 11.5 vs. 6.5, HR 0.59, $p=0.001$ ) for the triplet arm compared to the control group was shown. Subgroup analysis revealed that PFS benefit was also maintained in high-risk patients (median PFS 7.5 vs. 3.7 months, HR 0.66, 95\% CI 0.30-1.28). The median OS was NR in either group, although a trend to improved OS was observed in the triplet arm (HR $0.687,95 \%$ CI $0.461-1.023 ; p=0.06$ ) [37]. Regarding the safety profile, Isa-Pd induced a slightly higher rate of grade $3-4$ infections $(42.8 \%$ vs. $30.2 \%)$ and neutropenia $(84.9 \%$ vs. $70.1 \%$ ) [50]. The ongoing phase III IKEMA trial is evaluating the combination of isatuximab with $\mathrm{Kd}$ in RRMM patients (NCT03275285).

In transplant-ineligible NDMM patients, isatuximab $(10 \mathrm{mg} / \mathrm{kg})$ is being evaluated in a phase $\mathrm{Ib}$ trial in combination with VRd as induction (4 cycles) followed by maintenance with Isa-Rd. Preliminary results showed an ORR of $93 \%$, with $38.5 \%$ of patients achieving MRD negativity [47]. Another phase $\mathrm{Ib}$ trial is evaluating induction with 12 cycles of isatuximab $(10 / 20 \mathrm{mg} / \mathrm{kg})$ plus bortezomib-cyclophosphamide-dexamethasone (VCd), followed by maintenance with single-agent isatuximab in a similar patient population. The ORR was $87 \%$, whereas data on MRD status and PFS are not yet available [48].

In order to improve the poor prognosis of high-risk patients, a phase Ib trial that was specifically designed for high-risk NDMM patients is currently testing a quadruplet regimen combining isatuximabcarfilzomib-lenalidomide-dexamethasone (GMMG-CONCEPT trial [59]).

Finally, the phase III IMROZ study is currently comparing the quadruplet isatuximab-VRd (Isa-VRd) to VRd as upfront treatment for transplant-ineligible patients (NCT03319667). Another ongoing trial is comparing the quadruplet Isa-VRd to isatuximab-VCd (Isa-VCd) in transplant-ineligible patients at diagnosis (NCT02513186).

\section{MOR202 and TAK-079}

MOR202 and TAK-079 are two anti-CD38 mAbs under development. In preliminary trials, MOR202 proved to be effective in combination with IMiDs; as expected, as this agent does not seem to induce CDC, a low rate of IRRs was observed (10\%) [60,61]. In detail, the ORR was $28 \%$ in patients receiving MOR202 plus dexamethasone, which increased up to $65 \%$ in those receiving MOR202 plus 
$\mathrm{Rd}$ and to $43 \%$ in those receiving MOR202 with Pd. However, further development of MOR202 has been discontinued in the United States and Europe. Subcutaneous TAK-079 is currently being tested in preliminary clinical trials on RRMM patients as monotherapy (NCT03439280) and in combination with standard regimens Rd or VRd (NCT03984097). We still need to further define the role of newer anti-CD38 mAbs in the treatment scenario for MM, where daratumumab and isatuximab have proven high efficacy and manageability.

\subsection{Anti-Signaling Lymphocytic Activation Molecule Family 7 (SLAMF7) Monoclonal Antibodies}

\subsubsection{Rationale}

Signaling lymphocytic activation molecule family 7 (SLAMF7 or CS1) is a cell surface glycoprotein whose expression is essentially restricted to NK cells and both normal and abnormal plasma cells, with 95\% of myeloma plasma cells being SLAMF7-positive [62]. In plasma cells and MM cells, the SLAMF7 pathway promotes cell growth and survival, as well as the interaction with the bone marrow micro-environment. Its highly selective expression on plasma cells makes SLAMF7 an optimal target for mAbs.

\subsubsection{Clinical Development}

Elotuzumab is a humanized IgG-1 monoclonal antibody targeting SLAMF7 that promotes NK-mediated ADCC, directly activates NK cells and interferes with the MM cell adhesion to the bone marrow stromal cells [63-65]. Elotuzumab showed no clinically meaningful activity when administered as a single agent-in a phase I dose-escalating study, the best response achieved by RRMM patients treated at different doses of elotuzumab was stable disease (SD, 26\%) [66] (Table 3).

Table 3. Results of the main clinical trials with anti-signaling lymphocytic activation molecule family 7 (SLAMF7) monoclonal antibody elotuzumab.

\begin{tabular}{cccccccc}
\hline Study & Phase & $\begin{array}{c}\text { Number } \\
\text { of Patients }\end{array}$ & $\begin{array}{c}\text { Median } \\
\text { Previous } \\
\text { Line }\end{array}$ & Regimen & ORR & $\begin{array}{c}\text { Median } \\
\text { PFS } \\
\text { (Months) }\end{array}$ & $\begin{array}{c}\text { Median OS } \\
\text { (Months) }\end{array}$ \\
\hline NCT00425347 [66] & I & 35 & 5 & Elo $(0.5-20 \mathrm{mg} / \mathrm{kg})$ & 0 & NA & NA \\
\hline $\begin{array}{c}\text { ELOQUENT-2 } \\
{[67,68]}\end{array}$ & III & 321 & 2 & Elo-Rd vs. Rd & $\begin{array}{c}79 \% \text { vs. } \\
66 \%\end{array}$ & $\begin{array}{c}19.4 \\
\text { vs.14.9 }\end{array}$ & 48 vs. 40 \\
\hline ELOQUENT-3 [69] & II & 117 & 3 & $\begin{array}{c}\text { Elo-Poma-dex vs. } \\
\text { Pd }\end{array}$ & $53 \%$ vs.26\% & 10.3 vs. 4.7 & NA \\
\hline NCT00726869 [70] & I & 28 & 2 & Elo-V & $48 \%$ & 9.5 & NA \\
\hline NCT01478048 [71] & II & 152 & NA & Elo-Vd vs. Vd & $\begin{array}{c}66 \% \text { vs. } \\
63 \%\end{array}$ & $\begin{array}{c}9.7 \text { vs. } 6.9 \\
\text { 2-year OS 73\% } \\
\text { vs. 66\% }\end{array}$ \\
\hline
\end{tabular}

Abbreviations: Elo, elotuzumab; ORR, overall response rate; PFS, progression-free survival; OS, overall survival; $\mathrm{d}$, dex, dexamethasone; R, lenalidomide; Poma, pomalidomide; V, bortezomib; NR, not reached; NA, not yet available.

Preclinical data showed a synergistic activity of elotuzumab with IMiDs, the latter altering cytokine production and enhancing the activity of NK cells, the main target of elotuzumab immune activity. Promising results in terms of efficacy and tolerability were observed combining elotuzumab with Rd in phase I and II studies, thus providing the rationale for the phase III study ELOQUENT-2, which compared elotuzumab-Rd (Elo-Rd) to Rd in RRMM patients that were not refractory to lenalidomide [67,68,72]. In this study, elotuzumab was administered at the dose of $10 \mathrm{mg} / \mathrm{kg}$ and treatment was continued until progression or intolerance [66]. The triplet regimen containing elotuzumab proved to be more effective than Rd in terms of both PFS (19.4 vs. 14.9 months, HR 0.70, $p<0.001)$ and OS (48 vs. 40 months), without adding significant toxicity [73,74]. Patients at first relapse after a remission duration $>3.5$ years obtained the greater PFS advantage with Elo-Rd [75], showing that the greatest benefit with Elo-Rd could be obtained in patients with a slow and indolent 
progression. Elo-Rd is currently approved by both the FDA and EMA for the treatment of RRMM patients after 1 line of therapy.

The synergistic activity between elotuzumab and IMiDs prompted the investigators to test elotuzumab both in the upfront setting in combination with lenalidomide and at relapse with the third-generation IMiD pomalidomide [76]. The ongoing phase III study ELOQUENT-1, whose results are not yet available, enrolled NDMM patients ineligible for high-dose melphalan and ASCT in order to investigate the benefit of the addition of elotuzumab to the standard doublet Rd, possibly establishing a new standard of care in this setting.

In the randomized phase II ELOQUENT-3 trial, the addition of elotuzumab to Pd in RRMM patients significantly increased the ORR ( $53 \%$ vs. $26 \%$ ) and prolonged median PFS (10.3 vs. 4.7 months, HR $0.54, p=0.008$ ), as compared to Pd alone. Again, the safety profiles of the two arms of the study were overlapping, meaning that elotuzumab did not add significant toxicity to $\mathrm{Pd}$ [69]. On this basis, in 2018 the FDA approved the triplet elotuzumab-Pd for the treatment of RRMM patients who had received at least 2 prior regimens including lenalidomide and a PI.

In preclinical models, elotuzumab activity was potentiated by bortezomib, which makes myeloma cells more vulnerable to NK-mediated lysis [77]. This combination was subsequently tested in clinical trials. In a phase I study on RRMM patients, elotuzumab was combined with bortezomib, showing an ORR of $48 \%$ and a median time to progression of 9.5 months [70]. The triplet elotuzumab-Vd (Elo-Vd, with elotuzumab administered at $10 \mathrm{mg} / \mathrm{kg}$ ) was subsequently compared to $\mathrm{Vd}$ in a phase II trial on 152 RRMM patients, half of which had already received bortezomib in previous lines of therapy. ORR was similar between the two groups (66\% vs. $63 \%$ ), and a slight PFS advantage was observed in the triplet arm that nonetheless did not reach statistical significance (median, 9.7 vs. 6.9 months, HR 0.72, $p=0.09$ ) [71]. The most common grade $\geq 3$ AEs were infections (Elo-Vd 21\% vs. Vd 13\%) and thrombocytopenia (Elo-Vd 9\% vs. Vd 17\%). Because elotuzumab elicits its action by binding its Fc portion to the Fc gamma receptor III on NK cells, different allelic variants of the receptor were analyzed to evaluate possible predictors of elotuzumab efficacy. In this study, patients homozygous for the high-affinity Fc gamma receptor IIIa (Fc $\gamma$ RIIIa) V allele showed longer PFS as compared to patients homozygous for the low-affinity allele. Considering the number of treatment options currently approved, the availability of a predictor of response could help clinicians in the choice of the most appropriate treatment.

Elotuzumab-Rd has also been investigated as a prevention strategy in high-risk SMM. In a phase II study (NCT02279394), patients received 8 cycles of elotuzumab-Rd and were subsequently allowed to continue with elotuzumab and lenalidomide maintenance until progression to symptomatic MM [78]. Preliminary data showed an ORR of $84 \%$ with no patients progressing at MM at the present follow-up of 29 months. Grade 3-4 toxicities included neutropenia (16\%) and infections (12\%), mainly related to lenalidomide. Again, single-agent elotuzumab did not show any clinical activity when in the setting of SMM [79].

Of interest, the rate of IRRs observed with elotuzumab-which were mostly mild in nature (grades 1-2) and rarely leading to treatment discontinuation-was definitely lower (10\%) than that observed with other mAbs, making elotuzumab-based combinations appealing options for the treatment of frail patients [80].

Numerous studies are currently ongoing with elotuzumab-based combinations, such as elotuzumabVRd (Elo-VRd, NCT02375555), elotuzumab-KRd (Elo-KRd, NCT02969837) and elotuzumab plus pomalidomide-bortezomib-dexamethasone (NCT02718833).

\subsection{Anti-Programmed Death 1 (PD-1) Monoclonal Antibodies}

\subsubsection{Rationale}

The programmed death 1 (PD-1) receptor is a transmembrane glycoprotein expressed on antigen-activated T cells and B cells. The binding of PD-1 ligands (PD-1-L1 and PD-1-L2) on PD-1 
receptor results in the downregulation of immune T cell functions [81]. Preclinical data showed that PD-1/L1 is highly expressed on myeloma cells and, at variable levels, on normal plasma cells. It is also expressed at high levels on dendritic cells in the myeloma microenvironment $[82,83]$. Moreover, $\mathrm{T}$ cells derived from myeloma patients showed higher rates of PD-1 expression as compared to $\mathrm{T}$ cells from healthy donors, suggesting that the PD-1/PD-L1 pathway plays an important role in the immune escape of myeloma cells. Given these premises, targeting PD-1 and PD-L1 with monoclonal antibodies seems to be a promising strategy for the treatment of MM.

\subsubsection{Clinical Development}

Monoclonal antibodies directed against the PD-1/PD-L1 pathway can be divided into molecules targeting PD-1 (e.g., pembrolizumab and cemiplimab) and molecules targeting PD-L1 (e.g., durvalumab). Pembrolizumab monotherapy did not show efficacy as a single agent in 30 heavily pretreated myeloma patients (4 median prior lines of therapy) [84]. Pembrolizumab was subsequently combined with immunomodulatory agents, as preclinical data suggested that IMiDs could contribute to the downregulation of the PD-1/PD-L1 pathway [85]. In phase II trials, ORR was 50\% in RRMM patients receiving pembrolizumab plus $\mathrm{Rd}$ and $60 \%$ in patients receiving pembrolizumab plus $\mathrm{Pd}$ [86]. However, in 2017, following the preliminary results of the two randomized phase III trials KEYNOTE 185 (pembrolizumab-Rd vs. Rd) and KEYNOTE 183 (pembrolizumab-Pd vs. Pd), the FDA prompted the discontinuation of any further investigations of these combinations, in light of the increased risk of death for patients in the pembrolizumab group versus the control group (HR for OS in pembrolizumab-Pd vs. $\mathrm{Pd} 1.61$; $\mathrm{HR}$ for OS in pembrolizumab-Rd vs. $\mathrm{Rd} 2.06)[87,88]$. The main concern with this combination is indeed the increased risk of enhancing immune-mediated toxicity, resulting in various AEs, such as dermatologic, pulmonary, cardiac, gastrointestinal and hepatic toxicities. These results questioned the utility of anti-PD-1 mAbs in MM, at least in combination with IMiDs. Different molecules are currently under evaluation in combination with other agents. The anti-PD-1 cemiplimab is being evaluated in a phase I/II trial in combination with isatuximab (NCT03194867), whereas durvalumab is being tested in combination with daratumumab (NCT03000452). However, the future role of this class of molecules in the treatment of MM remains debated.

\section{Antibody Drug Conjugates}

\subsection{Rationale}

Antibody drug conjugates (ADCs) are monoclonal antibodies bound by a chemical linker to a cytotoxic compound directed against surface antigens of the targeted cells. ADCs selectively target cells expressing their target antigen and are then internalized releasing the cytotoxic component through lysosome degradation, causing cell death. This targeted delivery limits the systemic exposure to the cytotoxic compound, sparing the non-malignant cells and tissues that do not express the target antigen, consequently limiting its off-target toxic effects $[89,90]$. In the past few years, interest has been raised around ADCs for the treatment of lymphoid malignancies, with brentuximab vedotin being the first agent of this class to receive FDA and EMA approval for the treatment of relapsed/refractory Hodgkin lymphoma and anaplastic large cell lymphoma in 2011-2012 [91,92]. In MM, ADCs showed preclinical activity in in vitro and in xenograft models and are currently under evaluation in clinical trials for relapsed MM patients [93-95]. One of the main challenges with ADCs is the choice of the most appropriate surface antigens to be targeted, which should be highly expressed only on malignant cells and not on normal tissues. Several target antigens have been identified on plasma cells: CD56, CD138, CD74, Fc receptor-like 5 and B cell maturation antigen (BCMA) [96]; of these, CD56 is expressed only on MM cells, with no expression on normal plasma cells, whereas other antigens are expressed on both malignant and non-malignant plasma cells, although at different levels [97]. The cytotoxic compound is typically a small molecular weight toxin with potent activity at low concentrations. Such molecules, usually not employed for systemic chemotherapy due to their excessive toxicity, can cause cell death due 
to two different mechanisms: cell cycle interference through microtubules inhibitions and DNA damage. Maytansinoid derivatives are microtubule inhibitors, including DM1 (emtansine and mertansine), DM4 (soravtansine and ravtansine) and auristatin derivatives (including monomethyl-auristatin E (MMAE, vedotin) and monomethyl auristatin F (MMAF, mafodotin)) [98-101]. Calicheamicins, duocarymycins and pyrrolobenzodiazepine dimmers are DNA-damaging agents [102,103].

\subsection{Clinical Development}

Table 4 summarizes the results of the main studies with ADCs in MM.

Table 4. Results of preliminary clinical trials with antibody-drug conjugates (ADCs).

\begin{tabular}{|c|c|c|c|c|c|c|}
\hline Study & Phase & $\mathrm{ADC}$ & Target & $\begin{array}{l}\text { Cytotoxic } \\
\text { Agent }\end{array}$ & Respinse & $\begin{array}{l}\text { Key Toxicities } \\
\text { (G3-4) }\end{array}$ \\
\hline $\begin{array}{l}\text { NCT02064387 } \\
{[104-106]}\end{array}$ & I & GSK2857916 & BCMA & MMAF & $\begin{array}{l}\text { ORR } 60 \% \\
\text { PFS } 12 \mathrm{~m}\end{array}$ & $\begin{array}{c}\text { Thrombocyotpenia } 35 \% \\
\text { Corneal events } 14 \%\end{array}$ \\
\hline $\begin{array}{c}\text { NCT01001442 } \\
\text { [107] }\end{array}$ & I & Indatuximab-ravtansine & CD138 & DM4 & $\begin{array}{l}\text { ORR } 6 \% \\
\text { PFS } 3 \mathrm{~m} \\
\text { OS } 26 \mathrm{~m}\end{array}$ & $\begin{array}{c}\text { Fatigue }(7 \%) \\
\text { Anemia }(7 \%) \\
\text { Diarrhea }(4 \%)\end{array}$ \\
\hline $\begin{array}{c}\text { NCT01638936 } \\
{[108]}\end{array}$ & & $\begin{array}{c}\text { Indatuximab-ravtansine } \\
+ \text { Rd or } \\
+ \text { Poma-dex }\end{array}$ & CD138 & DM4 & $\begin{array}{c}\text { ORR } 77 \% \\
\text { PFS } 16.4 \mathrm{~m} \\
\text { ORR } 79 \% \\
\text { PFS NR }\end{array}$ & $\begin{array}{l}\text { Diarrhea } \\
\text { Fatigue } \\
\text { Nausea }\end{array}$ \\
\hline $\begin{array}{c}\text { NCT00991562 } \\
\text { [109] }\end{array}$ & I & Lorvotuzumab-mertansine & CD56 & DM1 & $\begin{array}{l}\text { ORR 6\% } \\
\text { PFS } 6.5 \mathrm{~m}\end{array}$ & $\begin{array}{l}\text { Peripheral neuropathy } \\
\qquad(5.3 \%)\end{array}$ \\
\hline $\begin{array}{l}\text { NCT01101594 } \\
\text { [110] }\end{array}$ & I & Milatuzumab-doxorubicin & CD74 & Doxorubicin & ORR $0 \%$ & $\begin{array}{c}\text { Anemia }(4 \%) \\
\text { Back pain }(4 \%) \\
\text { CRS }(4 \%)\end{array}$ \\
\hline
\end{tabular}

Abbreviations: R, lenalidomide; d, dex, dexamethasone; ORR, overall response rate; PFS, progression-free survival; OS, overall survival; NR, not reached; CRS, cytokine release syndrome; G, grade; MMAF, monomethyl auristatin F; BCMA, B cell maturation antigen.

In 2018, the results of a first in-human phase I study investigating GSK2857916, a BCMA-targeting $\mathrm{mAb}$ conjugated to the antimitotic agent monomethyl auristatin F (MMAF), in 73 RRMM patients were published. BCMA, a transmembrane receptor required for B cell maturation, was chosen as an optimal target, as it is expressed almost exclusively on MM cells and plasma cells [104-106]. In the dose-escalation phase of the study, 38 patients received escalating doses of IV GSK2857916 $(0.03-4.6 \mathrm{mg} / \mathrm{kg})$ every 3 weeks. In the dose-expansion phase of the study, 35 patients received the recommended phase II dose of GSK2857916 $(3.4 \mathrm{mg} / \mathrm{kg})$ every 3 weeks until progression. Among heavily pre-treated patients, GSK2857916 induced an objective response in 60\% of them, with 15\% of patients achieving a CR or a stringent CR (sCR). Remarkably, the ORR in patients previously treated with anti-CD38 mAbs and refractory to both IMiDs and PIs was 38\%. Responses were rapid (median time to response 1.2 months) and durable (median duration of response 14.3 months). Overall, median PFS was 12 months; median PFS was 7.9 months in double-refractory patients (to IMiDs and PIs) and 6.2 months in double-refractory patients with prior daratumumab. The most common treatment-related toxicities were thrombocytopenia (63\%; grades 3-4: 26\%) and corneal events in terms of blurred vision and photophobia (51\%; grades 3-4: 3\%). Ocular toxicity was mainly limited to grades 1-2 and was reversible and easily manageable with dose reductions (51\% of patients) [104,106]. Because GSK285791 showed high ORR in patients previously treated with anti-CD38 mAbs, a phase I/II clinical trial exploring its efficacy as monotherapy in patients with previous exposure to daratumumab/isatuximab has recently completed enrollment and results will soon be available (NCT03525678). Ongoing trials are evaluating its safety and efficacy in combination with pembrolizumab (NCT03848845), pomalidomide (NCT03715478), and lenalidomide versus bortezomib (NCT03544281).

Indatuximab-ravtansine (BT062) is an anti-CD138 IgG4 monoclonal antibody that delivers the microtubule inhibitor maytansinoid ravtansine to CD138-positive cells. CD138 is a transmembrane protein receptor upregulated by myeloma cells. BT062 monotherapy was evaluated in 67 heavily 
pretreated RRMM patients (median previous therapies 7, range 1-15). The most common grade 3-4 toxicities were fatigue $(7 \%)$, anemia $(7 \%)$, and diarrhea (4\%). At the maximum tolerated dose (MTD) of BT062 $\left(140 \mathrm{mg} / \mathrm{m}^{2}\right), 62 \%$ of patients achieved SD, whereas an objective response was observed in 5\% of patients only. Median PFS and OS were 3 and 26 months, respectively [107]. BT062 is currently under evaluation in combination with lenalidomide or pomalidomide plus dexamethasone in RRMM patients. In patients receiving BT062 + lenalidomide $(n=47)$, ORR was $77 \%$ and median PFS was 16.4 months, whereas in those receiving the ADC in combination with pomalidomide $(n=17)$ ORR was $79 \%$ and median PFS was NR after 7 months of follow-up. These triplets were well tolerated, with main AEs being fatigue and diarrhea [108].

Lorvotuzumab-mertansine (IMGN901) is an anti-CD56 mAb linked to the maytansinoid mertansine, which inhibits microtubules assembly interfering with cell cycle and therefore causing cell death. A phase I trial enrolling 37 heavily pre-treated patients ( $78 \%$ had $\geq 3$ lines of therapy) with CD56+ RRMM explored the safety and efficacy of single-agent IMGN901. The MTD was established at $112 \mathrm{mg} / \mathrm{m}^{2}$. Forty-three percent of patients experienced SD, 6\% PR, and no patient reached a very good (VG)PR or better, with a median PFS of 6.5 months. The toxicity profile was manageable and drug discontinuation due to AEs was observed in $24 \%$ of patients, with peripheral neuropathy (grades 3-4: 5.3\%) being the most common toxicity leading to discontinuation [109]. IMGN901 is also being evaluated in combination with Rd. Preliminary reports showed an ORR of $56 \%$, including 2 CRs and 8 VGPRs. The most common toxicity was peripheral neuropathy, although no grade $3-4$ events occurred at the MTD of $75 \mathrm{mg} / \mathrm{m}^{2}$ [111].

ADCs, particularly GSK285791, displayed a promising efficacy among heavily pre-treated patients. Their unique mechanism of action and preliminary efficacy data make these drugs an appealing treatment option in patients who have become refractory to IMiDs, PIs, and anti-CD38. Furthermore, the lack of cross-resistance with currently approved agents also prompts their investigation in the earlier phase of the disease, such as in the context of a consolidation strategy in high-risk patients or those MRD-positive after the induction/transplant phases.

Other compounds are under preliminary evaluation in MM. CD74, a transmembrane glycoprotein expressed in more than $90 \%$ of $\mathrm{B}$ cell malignancies, is the target of the ADC milatuzumab-doxorubicin (of hLL1-DOX) [110]. In a preliminary study, the ADC proved to be well tolerated, with SD being the best response achieved (26\% patients) with this agent used as monotherapy for RRMM patients [112]. Preclinical results showing synergistic activity of hLL1-DOX with PIs and IMiDs provide the biological rationale for the evaluation of this $\mathrm{ADC}$ in combination with other agents.

\section{Bispecific T Cell Engagers}

Bispecific monoclonal antibodies are engineered molecules meant to redirect immune effector cells, mainly $\mathrm{T}$ and NK cells, to tumor cells, thus restoring the immune suppressor activity of the immune system against neoplastic cells. Bispecific $\mathrm{T}$ cell engager molecules are a class of bispecific antibodies combining the minimal binding domains (variable fragments (Fv), single chains) of two different monoclonal antibodies on one polypeptide chain [113]. They are characterized by a small size, allowing optimal proximity between the engaged $\mathrm{T}$ cell and the target tumor cell; for this very reason, they are active at low concentrations, as compared to bispecific antibodies. Bispecific antibodies usually link the invariant part of CD3 of the T cell receptor (TCR) on T cells and a tumor-specific antigen, thus leading to $\mathrm{T}$ cell activation and proliferation and tumor cell apoptosis [114]. The first approved bispecific $T$ cell engager was the anti-CD19 blinatumomab for the treatment of RR B cell acute lymphoblastic leukemia [115].

Among potential targets on plasma cells, BCMA, CD38 and SLAMF7 have been chosen to design anti-MM bispecific antibodies [23,116], with BCMA representing the most promising target. Another potential target due to its high expression on PC is G-protein coupled receptor $C$ family $5 \mathrm{D}$ (GPRC5D), whose function is still unclear $[117,118]$. 


\section{Clinical Development}

AMG420 is an anti-BCMA bispecific T cell engager that is currently being evaluated in the first in-human dose escalation trial enrolling RRMM patients (4 median prior lines of therapy). AMG420 was administered as a continuous intravenous infusion due to its short half-life at doses ranging from 0.2 to $800 \mathrm{mcg} / \mathrm{die}$. At the MTD of $400 \mathrm{mcg} / \mathrm{day}$, the ORR was 70\%, with 5/10 patients obtaining MRD-negative sCRs $\left(10^{-4}\right)$ [119]. Dose-limiting toxicities were cytokine release syndrome (CRS, 1 patient) and peripheral neuropathy (2 patients). Only 1 grade 3 CRS was observed, and no grade 3-4 AEs related to the central nervous system were registered at the MTD. Another anti-BCMA BiTE $^{\circledR}$, AMG 701, has a longer half-life (112 h), thus allowing weekly short-term infusion. AMG 701 is currently being investigated in the first phase I trial [120].

BiTEs ${ }^{\circledR}$ currently under investigation are listed in Table 5.

Table 5. Bispecific T cell-engaging agents $\left(\mathrm{BiTEs}^{\circledR}\right)$ for the treatment of multiple myeloma.

\begin{tabular}{ccc}
\hline ClinicalTrials.Gov ID & Agent & Target \\
\hline NCT02514239 & AMG 420 & BCMA \\
NCT03287908 & AMG 701 & BCMA \\
NCT03486067 & CC-93269 & BCMA \\
NCT03145181 & JNJ-64007957 & BCMA \\
NCT03269136 & PF-06863135 & BCMA \\
NCT03761108 & REGN5458 & BCMA \\
NCT03399799 & JNJ-64407564 & GPRC5D \\
NCT03309111 & GBR 1342 & CD38
\end{tabular}

Abbreviations: $\mathrm{BCMA}, \mathrm{B}$ cell maturation antigen; CPRC5D, G-protein coupled receptor C family 5D.

\section{Conclusions and Future Directions}

Immunotherapy, and in particular mAbs, is no longer an appealing future perspective, but rather a valuable present therapeutic option for MM patients-having demonstrated to induce a response where conventional agents had failed - to increase the depth of response obtained with standard regimens acting in synergy with them and, ultimately, to prolong both PFS and OS. The 'guiding star' in this treatment landscape is definitely the anti-CD38 $\mathrm{mAb}$, which rapidly turned from being a valid alternative for RRMM patients without further viable therapeutic options to being the backbone of virtually all present and future combinations adopted as frontline therapies. However, given the different combinations of both daratumumab and isatuximab with backbone therapies (available or under evaluation), we still need to define which anti-CD38 mAb should be used considering the unavailability of data on the superiority of one over the other. Another open issue is as to what could be the effectiveness of re-treatment with the same, or a different, CD38 mAb. Arguably, this last question will be answered in the near future, thanks to the increasing use of anti-CD38 mAb combinations in early lines. These issues are particularly challenging considering the wide heterogeneity of myeloma cell populations [121]. Immunotherapy seems to be a potential strategy for targeting virtually all tumor subclones, as effector mechanisms rely on the patient immune system. Ongoing studies are exploring the different potential mechanisms of resistance to anti-CD38 mAbs, as well as how to overcome them. Lower basal levels of the target antigen have been proposed as a possible mechanism of intrinsic resistance to mAbs [122,123]. Regarding daratumumab, the downregulation of CD38 on cell surfaces could partially explain the loss of response to mAb therapy [124]. Interestingly, myeloma cells exposed to isatuximab and MOR202 did not show such a downregulation [125,126]. An intriguing way to overcome the acquired resistance derived from antigen downregulation could be the addition of molecules able to re-induce CD38 expression on cell surface, such as all-trans retinoic acid (ATRA) or panobinostat $[127,128]$. Finally, other proposed mechanisms of resistance under evaluation include the modification of the expression of adhesion molecules and the overexpression of complement inhibitors. In the context of the currently available anti-CD38 combinations, the role 
of anti-SLAMF7 mAb-based combinations is unclear-both anti-CD38 and anti-SLAMF7 antibodies have been combined with the same backbones (Rd, Pd, Vd); both anti-CD38 and anti-SLAMF7 mAbs showed encouraging efficacy data even in high-risk patients, but not substantial enough to suggest an ability to completely overcome their adverse prognoses; and, finally, both mAbs have a very good safety profile. Studies showing the better efficacy of one $\mathrm{mAb}$ combination over the other are currently lacking. The role of both mAbs in the treatment of SMM also needs to be defined-their good safety profiles make them good candidates for the treatment of a still asymptomatic disease, but their efficacy and the possibility to improve OS still need to be shown. ADCs and BiTEs ${ }^{\circledR}$ are fascinating constructs potentially able to either carry toxic compounds or redirect $\mathrm{T}$ cells against MM cells in a very specific way, thus limiting off-target toxicities. The preliminary results obtained with single-agent ADCs or BiTEs ${ }^{\circledR}$ in heavily pre-treated patients are by far exceeding expectations, especially if compared to the results obtained with the currently available single-agent drugs. Future studies will shed light on their role in the treatment of MM patients and on their efficacy when used earlier in the course of the disease; they will also explore how to improve their feasibility and treatment compliance, especially in relation to the continuous intravenous infusion characteristic of the BiTEs ${ }^{\circledR}$ evaluated in MM thus far. In this field, the compounds showing the most encouraging preclinical results are bispecific antibodies with extended half-life such as the anti-BCMAs AMG701 and PF3135, which would allow a weekly administration $[129,130]$. Moreover, we still need to decipher the exact mechanisms of resistance and how to revert them, as well as the best drug-partners to enhance their efficacy in different settings. We have to devise the proper antigen selection and payload choice that will be critical for their success in the treatment of MM. MAbs can also be conjugated with radioisotopes in order to increase the antitumor effect of the molecules. Daratumumab has been combined with different radionuclides (e.g., actinium-225), resulting in an increased tumoricidal effect besides its Fc-effector functions in preclinical models [131]. Bispecific pretargeted radiolabeled antibodies showed an even greater biodistribution to tumor cells and, in future, can represent an appealing approach for the treatment of MM, especially for heavily pretreated patients who usually remain sensitive to radiation [132]. Regarding the use of $\mathrm{mAbs}$, another field of interest is the use of radiolabeled antibodies for imaging assessment with immuno-positron emission tomography (immuno-PET) [133]. Indeed, surface antigens expressed on myeloma cells could be a target for radiolabeled mAbs, which would allow highly specific tumor detection and precise response assessment. Daratumumab has already been labeled to different positron emitters showing excellent targeting in preclinical models [134-136]. With these premises, immuno-PET could represent a useful tool for imaging assessment and also for guiding treatment strategies, as this technique could potentially be used to predict the effectiveness of mAb therapy.

Another issue is timing, that is to say, the most appropriate phase of treatment or disease in which these different classes of drugs should be used-if at diagnosis, at the evidence of MRD persistence in an effort to eradicate a resistant clone, or at relapse once conventional treatments have failed. In a highly competitive setting, with few validated targets (CS1, CD38, BCMA) and many different technologies (ADC, BiTEs ${ }^{\circledR}$, chimeric antigen receptor [CAR] T cells), both preclinical and clinical studies are critical to identify the most promising compounds. Along with the refinement of the existing drug regimens and treatment strategies and the development of new ones, a better understanding of the role of the immune system in the pathogenesis of MM will certainly be necessary.

Author Contributions: Substantial contributions to the conception or design, F.B., R.M., M.B., and F.G.; acquisition, analysis, or interpretation of data, F.B., R.M., M.B., and F.G.; first draft, F.B., R.M., and F.G.; supervision, M.B. and F.G.; critical revision for important intellectual content, F.B., R.M., M.B., and F.G.; final approval of the version to be published, R.M., F.B., M.B., and F.G.; agreement to be accountable for all aspects of the work in ensuring that questions related to the accuracy or integrity of any part of the work are appropriately investigated and resolved, F.B., R.M., M.B., and F.G. All authors have read and agreed to the published version of the manuscript.

Funding: This research received no external funding. 
Conflicts of Interest: F.B. declares no competing financial interests. R.M. has received honoraria from Amgen, Celgene, Takeda, and Janssen, and served on the advisory boards for Janssen. M.B. has received honoraria from Sanofi, Celgene, Amgen, Janssen, Novartis, Bristol-Myers Squibb, and AbbVie, and has received research funding from Sanofi, Celgene, Amgen, Janssen, Novartis, Bristol-Myers Squibb, and Mundipharma. F.G. has received honoraria from Amgen, Bristol-Myers Squibb, Celgene, Janssen, and Takeda, and served on the advisory boards for Amgen, Bristol-Myers Squibb, Celgene, Janssen, Roche, Takeda, and AbbVie.

\section{References}

1. Turesson, I.; Velez, R.; Kristinsson, S.Y.; Landgren, O. Patterns of Improved Survival in Patients with Multiple Myeloma in the Twenty-First Century: A Population-Based Study. J. Clin. Oncol. 2010, 28, 830-834. [CrossRef] [PubMed]

2. Kristinsson, S.Y.; Anderson, W.F.; Landgren, O. Improved long-term survival in multiple myeloma up to the age of 80 years. Leukemia 2014, 28, 1346-1348. [CrossRef] [PubMed]

3. Howlader, N.; Noone, A.; Krapcho, M.; Miller, D.; Brest, A.; Yu, M.; Ruhl, J.; Tatalovich, Z.; Mariotto, A.; Lewis, D.; et al. SEER Cancer Statistics Review (CSR), 1975-2016; Based on November 2018 SEER Data Submission, Posted to the SEER Web Site, April 2019; National Cancer Institute: Bethesda, MD, USA, 2019. Available online: https://seer.cancer.gov/csr/1975_2016/ (accessed on 19 December 2019).

4. Kumar, S.; Paiva, B.; Anderson, K.C.; Durie, B.; Landgren, O.; Moreau, P.; Munshi, N.; Lonial, S.; Bladé, J.; Mateos, M.-V.; et al. International Myeloma Working Group consensus criteria for response and minimal residual disease assessment in multiple myeloma. Lancet. Oncol 2016, 17, e328-e346. [CrossRef]

5. Attal, M.; Lauwers-Cances, V.; Hulin, C.; Leleu, X.; Caillot, D.; Escoffre, M.; Arnulf, B.; Macro, M.; Belhadj, K.; Garderet, L.; et al. Lenalidomide, Bortezomib, and Dexamethasone with Transplantation for Myeloma. N. Engl. J. Med. 2017, 376, 1311-1320. [CrossRef] [PubMed]

6. De Tute, R.M.; Rawstron, A.C.; Gregory, W.M.; Child, J.A.; Davies, F.E.; Bell, S.E.; Cook, G.; Szubert, A.J.; Drayson, M.T.; Jackson, G.H.; et al. Minimal residual disease following autologous stem cell transplant in myeloma: Impact on outcome is independent of induction regimen. Haematologica 2016, 101, e69-e71. [CrossRef]

7. Oliva, S.; Gambella, M.; Gilestro, M.; Muccio, V.E.; Gay, F.; Drandi, D.; Ferrero, S.; Passera, R.; Pautasso, C.; Bernardini, A.; et al. Minimal residual disease after transplantation or lenalidomidebased consolidation in myeloma patients: A prospective analysis. Oncotarget 2017, 8, 5924-5935. [CrossRef]

8. Gay, F.; Cerrato, C.; Petrucci, M.T.; Zambello, R.; Gamberi, B.; Ballanti, S.; Omedè, P.; Palmieri, S.; Troia, R.; Spada, S.; et al. Efficacy of carfilzomib lenalidomide dexamethasone (KRd) with or without transplantation in newly diagnosed myeloma according to risk status: Results from the forte trial. J. Clin. Oncol. 2019, 37, Abstract \#8002 [ASCO 2019 Annual Meeting].

9. Paiva, B.; Cedena, M.T.; Puig, N.; Arana, P.; Vidriales, M.B.; Cordon, L.; Flores-Montero, J.; Gutierrez, N.C.; Martín-Ramos, M.L.; Martinez-Lopez, J.; et al. Minimal residual disease monitoring and immune profiling in multiple myeloma in elderly patients. Blood 2016, 127, 3165-3174. [CrossRef]

10. Rawstron, A.C.; Child, J.A.; de Tute, R.M.; Davies, F.E.; Gregory, W.M.; Bell, S.E.; Szubert, A.J.; Navarro-Coy, N.; Drayson, M.T.; Feyler, S.; et al. Minimal residual disease assessed by multiparameter flow cytometry in multiple myeloma: Impact on outcome in the Medical Research Council Myeloma IX Study. J. Clin. Oncol. 2013, 31, 2540-2547. [CrossRef]

11. Mateos, M.-V.; Dimopoulos, M.A.; Cavo, M.; Suzuki, K.; Jakubowiak, A.; Knop, S.; Doyen, C.; Lucio, P.; Nagy, Z.; Kaplan, P.; et al. Daratumumab plus Bortezomib, Melphalan, and Prednisone for Untreated Myeloma. N. Engl. J. Med. 2018, 378, 518-528. [CrossRef]

12. Munshi, N.C.; Avet-Loiseau, H.; Rawstron, A.C.; Owen, R.G.; Child, J.A.; Thakurta, A.; Sherrington, P.; Samur, M.K.; Georgieva, A.; Anderson, K.C.; et al. Association of Minimal Residual Disease With Superior Survival Outcomes in Patients With Multiple Myeloma: A Meta-analysis. JAMA Oncol. 2017, 3, 28-35. [CrossRef] [PubMed]

13. Giuliani, N.; Malavasi, F. Editorial: Immunotherapy in Multiple Myeloma. Front. Immunol. 2019, 10, 1945. [CrossRef] [PubMed]

14. Leo, R.; Boeker, M.; Peest, D.; Hein, R.; Bartl, R.; Gessner, J.E.; Seibach, J.; Wacker, G.; Deicher, H. Multiparameter analyses of normal and malignant human plasma cells: CD38++, CD56+, CD54+, cIg+ is the common phenotype of myeloma cells. Ann. Hematol. 1992, 64, 132-139. [CrossRef] [PubMed] 
15. Malavasi, F.; Funaro, A.; Roggero, S.; Horenstein, A.; Calosso, L.; Mehta, K. Human CD38: A glycoprotein in search of a function. Immunol. Today 1994, 15, 95-97. [CrossRef]

16. Cagnetta, A.; Cea, M.; Calimeri, T.; Acharya, C.; Fulciniti, M.; Tai, Y.-T.; Hideshima, T.; Chauhan, D.; Zhong, M.Y.; Patrone, F.; et al. Intracellular NAD+ depletion enhances bortezomib-induced anti-myeloma activity. Blood 2013, 122, 1243-1255. [CrossRef] [PubMed]

17. Ausiello, C.M.; la Sala, A.; Ramoni, C.; Urbani, F.; Funaro, A.; Malavasi, F. Secretion of IFN- $\gamma$, IL-6, Granulocyte-Macrophage Colony-Stimulating Factor and IL-10 Cytokines after Activation of Human Purified T Lymphocytes upon CD38 Ligation. Cell. Immunol. 1996, 173, 192-197. [CrossRef]

18. Van de Donk, N.W.C.J. Immunomodulatory effects of CD38-targeting antibodies. Immunol. Lett. 2018, 199, 16-22. [CrossRef]

19. Casneuf, T.; Xu, X.S.; Adams, H.C.; Axel, A.E.; Chiu, C.; Khan, I.; Ahmadi, T.; Yan, X.; Lonial, S.; Plesner, T.; et al. Effects of daratumumab on natural killer cells and impact on clinical outcomes in relapsed or refractory multiple myeloma. Blood Adv. 2017, 1, 2105-2114. [CrossRef]

20. Wang, Y.; Zhang, Y.; Hughes, T.; Zhang, J.; Caligiuri, M.A.; Benson, D.M.; Yu, J. Fratricide of NK Cells in Daratumumab Therapy for Multiple Myeloma Overcome by Ex Vivo-Expanded Autologous NK Cells. Clin. Cancer Res. 2018, 24, 4006-4017. [CrossRef]

21. Overdijk, M.B.; Verploegen, S.; Bögels, M.; van Egmond, M.; van Bueren, J.J.L.; Mutis, T.; Groen, R.W.; Breij, E.; Martens, A.C.; Bleeker, W.K.; et al. Antibody-mediated phagocytosis contributes to the anti-tumor activity of the therapeutic antibody daratumumab in lymphoma and multiple myeloma. MAbs 2015, 7, 311-320. [CrossRef]

22. Lammerts van Bueren, J.; Jakobs, D.; Kaldenhoven, N.; Roza, M.; Hiddingh, S.; Meesters, J.; Voorhorst, M.; Gresnigt, E.; Wiegman, L.; Ortiz Buijsse, A.; et al. Direct in Vitro Comparison of Daratumumab with Surrogate Analogs of CD38 Antibodies MOR03087, SAR650984 and Ab79. Blood 2014, 124, Abstract \#3474 [ASH 2014 56th Meeting].

23. Krejcik, J.; Casneuf, T.; Nijhof, I.S.; Verbist, B.; Bald, J.; Plesner, T.; Syed, K.; Liu, K.; van de Donk, N.W.C.J.; Weiss, B.M.; et al. Daratumumab depletes CD38+ immune regulatory cells, promotes T-cell expansion, and skews T-cell repertoire in multiple myeloma. Blood 2016, 128, 384-394. [CrossRef] [PubMed]

24. Chatterjee, S.; Daenthanasanmak, A.; Chakraborty, P.; Wyatt, M.W.; Dhar, P.; Selvam, S.P.; Fu, J.; Zhang, J.; Nguyen, H.; Kang, I.; et al. CD38-NAD+Axis Regulates Immunotherapeutic Anti-Tumor T Cell Response. Cell Metab. 2018, 27, 85-100. [CrossRef] [PubMed]

25. Van De Donk, N.W.; Adams, H.; Vanhoof, G.; Krejcik, J.; Van der Borght, K.; Casneuf, T.; Smets, T.; Axel, A.; Abraham, Y.; Ceulmans, H.; et al. Daratumumab in Combination with Lenalidomide Plus Dexamethasone Results in Persistent Natural Killer (NK) Cells with a Distinct Phenotype and Expansion of Effector Memory T-Cells in Pollux, a Phase 3 Randomized Study. Blood 2017, 130, Abstract \#3124 [ASH 2017 58th Meeting].

26. Van de Donk, N.W.C.J.; Richardson, P.G.; Malavasi, F. CD38 antibodies in multiple myeloma: Back to the future. Blood 2018, 131, 13-29. [CrossRef] [PubMed]

27. Van Der Veer, M.S.; De Weers, M.; Van Kessel, B.; Bakker, J.M.; Wittebol, S.; Parren, P.W.H.I.; Lokhorst, H.M.; Mutis, T. The therapeutic human CD38 antibody daratumumab improves the anti-myeloma effect of newly emerging multi-drug therapies. Blood Cancer J. 2011, 1, e41. [CrossRef]

28. Usmani, S.Z.; Weiss, B.M.; Plesner, T.; Bahlis, N.J.; Belch, A.; Lonial, S.; Lokhorst, H.M.; Voorhees, P.M.; Richardson, P.G.; Chari, A.; et al. Clinical efficacy of daratumumab monotherapy in patients with heavily pretreated relapsed or refractory multiple myeloma. Blood 2016, 128, 37-44. [CrossRef]

29. Dimopoulos, M.A.; Oriol, A.; Nahi, H.; San-Miguel, J.; Bahlis, N.J.; Usmani, S.Z.; Rabin, N.; Orlowski, R.Z.; Komarnicki, M.; Suzuki, K.; et al. Daratumumab, Lenalidomide, and Dexamethasone for Multiple Myeloma. N. Engl. J. Med. 2016, 375, 1319-1331. [CrossRef]

30. Palumbo, A.; Chanan-Khan, A.; Weisel, K.; Nooka, A.K.; Masszi, T.; Beksac, M.; Spicka, I.; Hungria, V.; Munder, M.; Mateos, M.V.; et al. Daratumumab, Bortezomib, and Dexamethasone for Multiple Myeloma. N. Engl. J. Med. 2016, 375, 754-766. [CrossRef]

31. Spencer, A.; Lentzsch, S.; Weisel, K.; Avet-Loiseau, H.; Mark, T.M.; Spicka, I.; Masszi, T.; Lauri, B.; Levin, M.-D.; Bosi, A.; et al. Daratumumab plus bortezomib and dexamethasone versus bortezomib and dexamethasone in relapsed or refractory multiple myeloma: Updated analysis of CASTOR. Haematologica 2018, 103, 2079-2087. [CrossRef] 
32. Chari, A.; Suvannasankha, A.; Fay, J.W.; Arnulf, B.; Kaufman, J.L.; Ifthikharuddin, J.J.; Weiss, B.M.; Krishnan, A.; Lentzsch, S.; Comenzo, R.; et al. Daratumumab plus pomalidomide and dexamethasone in relapsed and/or refractory multiple myeloma. Blood 2017, 130, 974-981. [CrossRef] [PubMed]

33. Chari, A.; Martinez-Lopez, J.; Mateos, M.-V.; Bladé, J.; Benboubker, L.; Oriol, A.; Arnulf, B.; Rodriguez-Otero, P.; Pineiro, L.; Jakubowiak, A.; et al. Daratumumab plus carfilzomib and dexamethasone in patients with relapsed or refractory multiple myeloma. Blood 2019, 134, 421-431. [CrossRef] [PubMed]

34. Martin, T.; Baz, R.; Benson, D.M.; Lendvai, N.; Wolf, J.; Munster, P.; Lesokhin, A.M.; Wack, C.; Charpentier, E.; Campana, F.; et al. A phase 1b study of isatuximab plus lenalidomide and dexamethasone for relapsed/refractory multiple myeloma. Blood 2017, 129, 3294-3303. [CrossRef] [PubMed]

35. Mikhael, J.; Richardson, P.; Usmani, S.Z.; Raje, N.; Bensinger, W.; Karanes, C.; Campana, F.; Kanagavel, D.; Dubin, F.; Liu, Q.; et al. A phase $1 \mathrm{~b}$ study of isatuximab plus pomalidomide/dexamethasone in relapsed/refractory multiple myeloma. Blood 2019, 134, 123-133. [CrossRef] [PubMed]

36. Chari, A.; Richter, J.R.; Shah, N.; Wong, S.W.K.; Jagannath, S.; Cho, H.J.; Biran, N.; Wolf, J.; Parekh, S.S.; Munster, P.N.; et al. Phase I-b study of isatuximab + carfilzomib in relapsed and refractory multiple myeloma (RRMM). J. Clin. Oncol. 2018, 36, Abstract \#8014 [ASCO 2018 Annual Meeting].

37. Attal, M.; Richardson, P.G.; Rajkumar, S.V.; San-Miguel, J.; Beksac, M.; Spicka, I.; Leleu, X.; Schjesvold, F.; Moreau, P.; Dimopoulos, M.A.; et al. Isatuximab plus pomalidomide and low-dose dexamethasone versus pomalidomide and low-dose dexamethasone in patients with relapsed and refractory multiple myeloma (ICARIA-MM): A randomised, multicentre, open-label, phase 3 study. Lancet 2019, 394, 2096-2107. [CrossRef]

38. Facon, T.; Kumar, S.; Plesner, T.; Orlowski, R.Z.; Moreau, P.; Bahlis, N.; Basu, S.; Nahi, H.; Hulin, C.; Quach, H.; et al. Daratumumab plus Lenalidomide and Dexamethasone for Untreated Myeloma. N. Engl. J. Med. 2019, 380, 2104-2115. [CrossRef]

39. Moreau, P.; Attal, M.; Hulin, C.; Arnulf, B.; Belhadj, K.; Benboubker, L.; Béné, M.C.; Broijl, A.; Caillon, H.; Caillot, D.; et al. Bortezomib, thalidomide, and dexamethasone with or without daratumumab before and after autologous stem-cell transplantation for newly diagnosed multiple myeloma (CASSIOPEIA): A randomised, open-label, phase 3 study. Lancet 2019, 394, 29-38. [CrossRef]

40. Voorhees, P.M.; Rodriguez, C.; Reeves, B.; Nathwani, N.; Costa, L.J.; Lutska, Y.; Hoehn, D.; Pei, H.; Ukropec, J.; Qi, M.; et al. Efficacy and Updated Safety Analysis of a Safety Run-in Cohort from Griffin, a Phase 2 Randomized Study of Daratumumab (Dara), Bortezomib (V), Lenalidomide (R), and Dexamethasone (D.; Dara-Vrd) Vs. Vrd in Patients (Pts) with Newly Diagnosed (ND) Multiple M. Blood 2018, 132, Abstract\#151 [ASH 2018 59th Meeting].

41. Lonial, S.; Weiss, B.M.; Usmani, S.Z.; Singhal, S.; Chari, A.; Bahlis, N.J.; Belch, A.; Krishnan, A.; Vescio, R.A.; Mateos, M.V.; et al. Daratumumab monotherapy in patients with treatment-refractory multiple myeloma (SIRIUS): An open-label, randomised, phase 2 trial. Lancet 2016, 387, 1551-1560. [CrossRef]

42. Dimopoulos, M.A.; San-Miguel, J.; Belch, A.; White, D.; Benboubker, L.; Cook, G.; Leiba, M.; Morton, J.; Ho, P.J.; Kim, K.; et al. Daratumumab plus lenalidomide and dexamethasone versus lenalidomide and dexamethasone in relapsed or refractory multiple myeloma: Updated analysis of POLLUX. Haematologica 2018, 103, 2088-2096. [CrossRef] [PubMed]

43. San Miguel, J.; Weisel, K.; Moreau, P.; Lacy, M.; Song, K.; Delforge, M.; Karlin, L.; Goldschmidt, H.; Banos, A.; Oriol, A.; et al. Pomalidomide plus low-dose dexamethasone versus high-dose dexamethasone alone for patients with relapsed and refractory multiple myeloma (MM-003): A randomised, open-label, phase 3 trial. Lancet Oncol. 2013, 14, 1055-1066. [CrossRef]

44. Amgen Announces Phase 3 CANDOR Study Combining KYPROLIS®(carfilzomib) And DARZALEX®(daratumumab) Meets Primary Endpoint of Progression-Free Survival. Available online: https: //www.amgen.com/media/news-releases/2019/09/amgen-announces-phase-3-candor-study-combiningkyprolis-carfilzomib-and-darzalex-daratumumab-meets-primary-endpoint-of-progressionfree-survival/ (accessed on 7 November 2019).

45. Sonneveld, P.; Attal, M.; Perrot, A.; Hulin, C.; Caillot, D.; Facon, T.; Leleu, X.; Belhadj-Merzoug, K.; Karlin, L.; Benboubker, L.; et al. Daratumumab Plus Bortezomib, Thalidomide, and Dexamethasone (D-VTd) in Transplant-eligible Newly Diagnosed Multiple Myeloma (NDMM): Subgroup Analysis of High-risk Patients (Pts) in CASSIOPEIA-International Myeloma Workshop (IMW) 2019 Abstract Book. 4 [Abstract \#OAB-003]. Available online: http://imw2019boston.org/images/Abstracts/17th_IMW_Abstract_Book_FINAL_V2.pdf (accessed on 12 December 2019). 
46. Sonneveld, P.; Broijl, A.; Gay, F.; Boccadoro, M.; Einsele, H.; Blade, J.; Dimopoulos, M.A.; Delforge, M.; Spencer, A.; Hajek, R.; et al. Bortezomib, lenalidomide, and dexamethasone (VRd) \pm daratumumab (DARA) in patients (pts) with transplant-eligible (TE) newly diagnosed multiple myeloma (NDMM): A multicenter, randomized, phase III study (PERSEUS). J. Clin. Oncol. 2019, 37, Abstract \#TPS8055 [ASCO 2019 Annual Meeting].

47. Ocio, E.M.; Otero, P.R.; Bringhen, S.; Oliva, S.; Nogai, A.; Attal, M.; Moreau, P.; Kanagavel, D.; Fitzmaurice, T.; $\mathrm{Wu}$, J.; et al. Preliminary Results from a Phase I Study of Isatuximab (ISA) in Combination with Bortezomib, Lenalidomide, Dexamethasone (VRd) in Patients with Newly Diagnosed Multiple Myeloma (NDMM) Non-Eligible for Transplant. Blood 2018, 132, Abstract \#595 [ASH 2018 60th Meeting].

48. Ocio, E.M.; Bringhen, S.; Oliva, S.; Rodriguez-Otero, P.; Kanagavel, D.; Oprea, C.; Wei, V.; Doroumian, S.; Martinez-Lopez, J. A Phase Ib Study of Isatuximab in Combination with Bortezomib, Cyclophosphamide, and Dexamethasone (VCDI) in Patients with Newly Diagnosed Multiple Myeloma Non-Eligible for Transplantation. Blood 2017, 130, Abstract \#3160 [ASH 2017 59th Annual Meeting].

49. Orlowski, R.Z.; Goldschmidt, H.; Cavo, M.; Martin, T.G.; Paux, G.; Oprea, C.; Facon, T. Phase III (IMROZ) study design: Isatuximab plus bortezomib (V), lenalidomide (R), and dexamethasone (d) vs VRd in transplant-ineligible patients (pts) with newly diagnosed multiple myeloma (NDMM). J. Clin. Oncol. 2018, 36, Abstract \#TPS8055 [ASCO 2018 Annual Meeting].

50. Richardson, P.G.; Attal, M.; Rajkumar, S.V.; San Miguel, J.; Beksac, M.; Spicka, I.; Leleu, X.; Schjesvold, F.; Moreau, P.; Dimopoulos, M.A.; et al. A phase III randomized, open label, multicenter study comparing isatuximab, pomalidomide, and low-dose dexamethasone versus pomalidomide and low-dose dexamethasone in patients with relapsed/refractory multiple myeloma (RRMM). J. Clin. Oncol. 2019, 37, Abstract \#8004 [ASCO 2019 Annual Meeting].

51. Mateos, M.-V.; Hernández, M.-T.; Giraldo, P.; de la Rubia, J.; de Arriba, F.; López Corral, L.; Rosiñol, L.; Paiva, B.; Palomera, L.; Bargay, J.; et al. Lenalidomide plus dexamethasone for high-risk smoldering multiple myeloma. N. Engl. J. Med. 2013, 369, 438-447. [CrossRef] [PubMed]

52. Hofmeister, C.C.; Chari, A.; Cohen, Y.; Spencer, A.; Voorhees, P.M.; Estell, J.; Venner, C.P.; Sandhu, I.; Jenner, M.W.; Williams, C.; et al. Daratumumab Monotherapy for Patients with Intermediate or High-Risk Smoldering Multiple Myeloma (SMM): Centaurus, a Randomized, Open-Label, Multicenter Phase 2 Study. Blood 2017, 130, Abstract \#510 [ASH 2017 59th Meeting].

53. Landgren, O.; Cavo, M.; Chari, A.; Cohen, Y.C.; Spencer, A.; Voorhees, P.M.; Estell, J.; Sandhu, I.; Jenner, M.; Williams, C.; et al. Updated Results from the Phase 2 Centaurus Study of Daratumumab (DARA) Monotherapy in Patients with Intermediate-Risk or High-Risk Smoldering Multiple Myeloma (SMM). Blood 2018, 132, Abstract \#1994 [ASH 2018 60th Meeting].

54. Barr, H.; Dempsey, J.; Waller, A.; Huang, Y.; Williams, N.; Sharma, N.; Benson, D.M.; Rosko, A.E.; Efebera, Y.A.; Hofmeister, C.C. Ninety-minute daratumumab infusion is safe in multiple myeloma. Leukemia 2018, 32, 2495-2518. [CrossRef] [PubMed]

55. Chari, A.; Nahi, H.; Mateos, M.-V.; Lokhorst, H.M.; Kaufman, J.L.; Moreau, P.; Oriol, A.; Plesner, T.; Benboubker, L.; Hellemans, P.; et al. Subcutaneous Delivery of Daratumumab in Patients (pts) with Relapsed or Refractory Multiple Myeloma (RRMM): Pavo, an Open-Label, Multicenter, Dose Escalation Phase 1b Study. Blood 2017, 130, Abstract \#838 [ASH 2017 59th Meeting].

56. Deckert, J.; Wetzel, M.-C.; Bartle, L.M.; Skaletskaya, A.; Goldmacher, V.S.; Vallee, F.; Zhou-Liu, Q.; Ferrari, P.; Pouzieux, S.; Lahoute, C.; et al. SAR650984, A Novel Humanized CD38-Targeting Antibody, Demonstrates Potent Antitumor Activity in Models of Multiple Myeloma and Other CD38+ Hematologic Malignancies. Clin. Cancer Res. 2014, 20, 4574-4583. [CrossRef]

57. Jiang, H.; Acharya, C.; An, G.; Zhong, M.; Feng, X.; Wang, L.; Dasilva, N.; Song, Z.; Yang, G.; Adrian, F.; et al. SAR650984 directly induces multiple myeloma cell death via lysosomal-associated and apoptotic pathways, which is further enhanced by pomalidomide. Leukemia 2016, 30, 399-408. [CrossRef] [PubMed]

58. Martin, T.; Strickland, S.; Glenn, M.; Charpentier, E.; Guillemin, H.; Hsu, K.; Mikhael, J. Phase I trial of isatuximab monotherapy in the treatment of refractory multiple myeloma. Blood Cancer J. 2019, 9, 41. [CrossRef] [PubMed] 
59. Weisel, K.; Asemissen, A.M.; Schieferdecker, A.; Besemer, B.; Zago, M.; Mann, C.; Lutz, R.; Benner, A.; Tichy, D.; Bokemeyer, C.; et al. Isatuximab, Carfilzomib, Lenalidomide and Dexamethasone (I-KRd) in front-line treatment of high-risk Multiple Myeloma: Results of the Safety Run-In cohort in the phase II, multicenter GMMG-CONCEPT trial-International Myeloma Workshop (IMW), 2019 Abstract. 2019, 25-26 [Abstract \#OAB-023]. Available online: http://imw2019boston.org/images/Abstracts/17th_IMW_Abstract_ Book_FINAL_V2.pdf (accessed on 12 December 2019).

60. Raab, M.S.; Goldschmidt, H.; Agis, H.; Blau, I.W.; Einsele, H.; Engelhardt, M.; Ferstl, B.; Gramatzki, M.; Röllig, C.; Weisel, K.; et al. A phase I/IIa study of the human anti-CD38 antibody MOR202 (MOR03087) in relapsed or refractory multiple myeloma (rrMM). J. Clin. Oncol. 2015, 33, Abstract \#8574 (ASCO 2015 Annual Meeting].

61. Raab, M.S.; Chatterjee, M.; Goldschmidt, H.; Agis, H.; Blau, I.; Einsele, H.; Engelhardt, M.; Ferstl, B.; Gramatzki, M.; Rollig, C.; et al. MOR202 with Low-Dose Dexamethasone (Dex) or Pomalidomide/Dex or Lenalidomide/Dex in Relapsed or Refractory Multiple Myeloma (RRMM): Primary Analysis of a Phase I/IIa, Multicenter, Dose-Escalation Study. Blood 2018, 132, Abstract \#153 [ASH 2018 60th Meeting].

62. Hsi, E.D.; Steinle, R.; Balasa, B.; Szmania, S.; Draksharapu, A.; Shum, B.P.; Huseni, M.; Powers, D.; Nanisetti, A.; Zhang, Y.; et al. CS1, a potential new therapeutic antibody target for the treatment of multiple myeloma. Clin. Cancer Res. 2008, 14, 2775-2784. [CrossRef] [PubMed]

63. Pazina, T.; James, A.M.; MacFarlane, A.W.; Bezman, N.A.; Henning, K.A.; Bee, C.; Graziano, R.F.; Robbins, M.D.; Cohen, A.D.; Campbell, K.S. The anti-SLAMF7 antibody elotuzumab mediates NK cell activation through both CD16-dependent and -independent mechanisms. Oncoimmunology 2017, 6, e1339853. [CrossRef]

64. Collins, S.M.; Bakan, C.E.; Swartzel, G.D.; Hofmeister, C.C.; Efebera, Y.A.; Kwon, H.; Starling, G.C.; Ciarlariello, D.; Bhaskar, S.; Briercheck, E.L.; et al. Elotuzumab directly enhances NK cell cytotoxicity against myeloma via CS1 ligation: Evidence for augmented NK cell function complementing ADCC. Cancer Immunol. Immunother. 2013, 62, 1841-1849. [CrossRef]

65. Tai, Y.-T.; Dillon, M.; Song, W.; Leiba, M.; Li, X.-F.; Burger, P.; Lee, A.I.; Podar, K.; Hideshima, T.; Rice, A.G.; et al. Anti-CS1 humanized monoclonal antibody HuLuc63 inhibits myeloma cell adhesion and induces antibody-dependent cellular cytotoxicity in the bone marrow milieu. Blood 2008, 112, 1329-1337. [CrossRef]

66. Zonder, J.A.; Mohrbacher, A.F.; Singhal, S.; van Rhee, F.; Bensinger, W.I.; Ding, H.; Fry, J.; Afar, D.E.H.; Singhal, A.K. A phase 1, multicenter, open-label, dose escalation study of elotuzumab in patients with advanced multiple myeloma. Blood 2012, 120, 552-559. [CrossRef]

67. Lonial, S.; Vij, R.; Harousseau, J.-L.; Facon, T.; Moreau, P.; Mazumder, A.; Kaufman, J.L.; Leleu, X.; Tsao, L.C.; Westland, C.; et al. Elotuzumab in combination with lenalidomide and low-dose dexamethasone in relapsed or refractory multiple myeloma. J. Clin. Oncol. 2012, 30, 1953-1959. [CrossRef]

68. Richardson, P.G.; Jagannath, S.; Moreau, P.; Jakubowiak, A.J.; Raab, M.S.; Facon, T.; Vij, R.; White, D.; Reece, D.E.; Benboubker, L.; et al. Elotuzumab in combination with lenalidomide and dexamethasone in patients with relapsed multiple myeloma: Final phase 2 results from the randomised, open-label, phase $1 \mathrm{~b}-2$ dose-escalation study. Lancet. Haematol. 2015, 2, e516-e527. [CrossRef]

69. Dimopoulos, M.A.; Dytfeld, D.; Grosicki, S.; Moreau, P.; Takezako, N.; Hori, M.; Leleu, X.; LeBlanc, R.; Suzuki, K.; Raab, M.S.; et al. Elotuzumab plus Pomalidomide and Dexamethasone for Multiple Myeloma. N. Engl. J. Med. 2018, 379, 1811-1822. [CrossRef]

70. Jakubowiak, A.J.; Benson, D.M.; Bensinger, W.; Siegel, D.S.D.; Zimmerman, T.M.; Mohrbacher, A.; Richardson, P.G.; Afar, D.E.H.; Singhal, A.K.; Anderson, K.C. Phase I Trial of Anti-CS1 Monoclonal Antibody Elotuzumab in Combination With Bortezomib in the Treatment of Relapsed/Refractory Multiple Myeloma. J. Clin. Oncol. 2012, 30, 1960-1965. [CrossRef]

71. Jakubowiak, A.; Offidani, M.; Pégourie, B.; De La Rubia, J.; Garderet, L.; Laribi, K.; Bosi, A.; Marasca, R.; Laubach, J.; Mohrbacher, A.; et al. Randomized phase 2 study: Elotuzumab plus bortezomib/dexamethasone vs bortezomib/dexamethasone for relapsed/refractory MM. Blood 2016, 127, 2833-2840. [CrossRef]

72. Cives, M.; Simone, V.; Brunetti, O.; Longo, V.; Silvestris, F. Novel lenalidomide-based combinations for treatment of multiple myeloma. Crit. Rev. Oncol. Hematol. 2013, 85, 9-20. [CrossRef]

73. Lonial, S.; Dimopoulos, M.; Palumbo, A.; White, D.; Grosicki, S.; Spicka, I.; Walter-Croneck, A.; Moreau, P.; Mateos, M.-V.; Magen, H.; et al. Elotuzumab Therapy for Relapsed or Refractory Multiple Myeloma. N. Engl. J. Med. 2015, 373, 621-631. [CrossRef] 
74. Dimopoulos, M.A.; Lonial, S.; Betts, K.A.; Chen, C.; Zichlin, M.L.; Brun, A.; Signorovitch, J.E.; Makenbaeva, D.; Mekan, S.; Sy, O.; et al. Elotuzumab plus lenalidomide and dexamethasone in relapsed/refractory multiple myeloma: Extended 4-year follow-up and analysis of relative progression-free survival from the randomized ELOQUENT-2 trial. Cancer 2018, 124, 4032-4043. [CrossRef]

75. Gavriatopoulou, M.; Terpos, E.; Dimopoulos, M.A. The extended 4-year follow-up results of the ELOQUENT-2 trial. Oncotarget 2019, 10, 82-83. [CrossRef]

76. Balasa, B.; Yun, R.; Belmar, N.A.; Fox, M.; Chao, D.T.; Robbins, M.D.; Starling, G.C.; Rice, A.G. Elotuzumab enhances natural killer cell activation and myeloma cell killing through interleukin-2 and TNF- $\alpha$ pathways. Cancer Immunol. Immunother. 2015, 64, 61-73. [CrossRef]

77. Van Rhee, F.; Szmania, S.M.; Dillon, M.; van Abbema, A.M.; Li, X.; Stone, M.K.; Garg, T.K.; Shi, J.; Moreno-Bost, A.M.; Yun, R.; et al. Combinatorial efficacy of anti-CS1 monoclonal antibody elotuzumab (HuLuc63) and bortezomib against multiple myeloma. Mol. Cancer Ther. 2009, 8, 2616-2624. [CrossRef]

78. Ghobrial, I.M.; Badros, A.Z.; Vredenburgh, J.J.; Matous, J.; Caola, A.M.; Savell, A.; Henrick, P.; Paba-Prada, C.E.; Schlossman, R.L.; Laubach, J.P.; et al. Phase II Trial of Combination of Elotuzumab, Lenalidomide, and Dexamethasone in High-Risk Smoldering Multiple Myeloma. Blood 2016, 128, Abstract \#976 [ASH 2016 58th Meeting].

79. Jagannath, S.; Laubach, J.; Wong, E.; Stockerl-Goldstein, K.; Rosenbaum, C.; Dhodapkar, M.; Jou, Y.-M.; Lynch, M.; Robbins, M.; Shelat, S.; et al. Elotuzumab monotherapy in patients with smouldering multiple myeloma: A phase 2 study. Br. J. Haematol. 2018, 182, 495-503. [CrossRef]

80. Weisel, K.; Paner, A.; Engelhardt, M.; Taylor, F.; Cocks, K.; Espensen, A.; Popa-McKiver, M.; Chen, C.; Cavo, M. Quality-of-Life Outcomes in Patients with Relapsed/Refractory Multiple Myeloma Treated with Elotuzumab Plus Pomalidomide and Dexamethasone: Results from the Phase 2 Randomized Eloquent-3 Study. Blood 2018, 132, Abstract \#2288 [ASH 2018 60th Meeting].

81. Parry, R.V.; Chemnitz, J.M.; Frauwirth, K.A.; Lanfranco, A.R.; Braunstein, I.; Kobayashi, S.V.; Linsley, P.S.; Thompson, C.B.; Riley, J.L. CTLA-4 and PD-1 receptors inhibit T-cell activation by distinct mechanisms. Mol. Cell. Biol. 2005, 25, 9543-9553. [CrossRef]

82. Paiva, B.; Azpilikueta, A.; Puig, N.; Ocio, E.M.; Sharma, R.; Oyajobi, B.O.; Labiano, S.; San-Segundo, L.; Rodriguez, A.; Aires-Mejia, I.; et al. PD-L1/PD-1 presence in the tumor microenvironment and activity of PD-1 blockade in multiple myeloma. Leukemia 2015, 29, 2110-2113. [CrossRef]

83. Ray, A.; Das, D.S.; Song, Y.; Richardson, P.; Munshi, N.C.; Chauhan, D.; Anderson, K.C. Targeting PD1-PDL1 immune checkpoint in plasmacytoid dendritic cell interactions with $\mathrm{T}$ cells, natural killer cells and multiple myeloma cells. Leukemia 2015, 29, 1441-1444. [CrossRef]

84. Ribrag, V.; Avigan, D.E.; Green, D.J.; Wise-Draper, T.; Posada, J.G.; Vij, R.; Zhu, Y.; Farooqui, M.Z.H.; Marinello, P.; Siegel, D.S. Phase $1 \mathrm{~b}$ trial of pembrolizumab monotherapy for relapsed/refractory multiple myeloma: KEYNOTE-013. Br. J. Haematol. 2019, 186, e41-e44. [CrossRef]

85. Görgün, G.; Samur, M.K.; Cowens, K.B.; Paula, S.; Bianchi, G.; Anderson, J.E.; White, R.E.; Singh, A.; Ohguchi, H.; Suzuki, R.; et al. Lenalidomide enhances immune checkpoint blockade-induced immune response in multiple myeloma. Clin. Cancer Res. 2015, 21, 4607-4618. [CrossRef]

86. Badros, A.; Hyjek, E.; Ma, N.; Lesokhin, A.; Dogan, A.; Rapoport, A.P.; Kocoglu, M.; Lederer, E.; Philip, S.; Milliron, T.; et al. Pembrolizumab, pomalidomide, and low-dose dexamethasone for relapsed/refractory multiple myeloma. Blood 2017, 130, 1189-1197. [CrossRef]

87. Mateos, M.-V.; Blacklock, H.; Schjesvold, F.; Oriol, A.; Simpson, D.; George, A.; Goldschmidt, H.; Larocca, A.; Chanan-Khan, A.; Sherbenou, D.; et al. Pembrolizumab plus pomalidomide and dexamethasone for patients with relapsed or refractory multiple myeloma (KEYNOTE-183): A randomised, open-label, phase 3 trial. Lancet Haematol. 2019, 6, e459-e469. [CrossRef]

88. Usmani, S.Z.; Schjesvold, F.; Oriol, A.; Karlin, L.; Cavo, M.; Rifkin, R.M.; Yimer, H.A.; LeBlanc, R.; Takezako, N.; McCroskey, R.D.; et al. Pembrolizumab plus lenalidomide and dexamethasone for patients with treatment-naive multiple myeloma (KEYNOTE-185): A randomised, open-label, phase 3 trial. Lancet Haematol. 2019, 6, e448-e458. [CrossRef]

89. Tolcher, A.W. Antibody drug conjugates: Lessons from 20 years of clinical experience. Ann. Oncol. 2016, 27, 2168-2172. [CrossRef]

90. Wolska-Washer, A.; Robak, P.; Smolewski, P.; Robak, T. Emerging antibody-drug conjugates for treating lymphoid malignancies. Expert Opin. Emerg. Drugs 2017, 22, 259-273. [CrossRef] 
91. Younes, A.; Gopal, A.K.; Smith, S.E.; Ansell, S.M.; Rosenblatt, J.D.; Savage, K.J.; Ramchandren, R.; Bartlett, N.L.; Cheson, B.D.; de Vos, S.; et al. Results of a Pivotal Phase II Study of Brentuximab Vedotin for Patients With Relapsed or Refractory Hodgkin's Lymphoma. J. Clin. Oncol. 2012, 30, 2183-2189. [CrossRef]

92. Pro, B.; Advani, R.; Brice, P.; Bartlett, N.L.; Rosenblatt, J.D.; Illidge, T.; Matous, J.; Ramchandren, R.; Fanale, M.; Connors, J.M.; et al. Brentuximab Vedotin (SGN-35) in Patients With Relapsed or Refractory Systemic Anaplastic Large-Cell Lymphoma: Results of a Phase II Study. J. Clin. Oncol. 2012, 30, 2190-2196. [CrossRef]

93. Tassone, P.; Gozzini, A.; Goldmacher, V.; Shammas, M.A.; Whiteman, K.R.; Carrasco, D.R.; Li, C.; Allam, C.K.; Venuta, S.; Anderson, K.C.; et al. In vitro and in vivo activity of the maytansinoid immunoconjugate huN901-N2'-deacetyl-N2'-(3-mercapto-1-oxopropyl)-maytansine against CD56+ multiple myeloma cells. Cancer Res. 2004, 64, 4629-4636. [CrossRef]

94. Tassone, P.; Goldmacher, V.S.; Neri, P.; Gozzini, A.; Shammas, M.A.; Whiteman, K.R.; Hylander-Gans, L.L.; Carrasco, D.R.; Hideshima, T.; Shringarpure, R.; et al. Cytotoxic activity of the maytansinoid immunoconjugate B-B4-DM1 against CD138+ multiple myeloma cells. Blood 2004, 104, 3688-3696. [CrossRef]

95. Stein, R.; Smith, M.R.; Chen, S.; Zalath, M.; Goldenberg, D.M. Combining Milatuzumab with Bortezomib, Doxorubicin, or Dexamethasone Improves Responses in Multiple Myeloma Cell Lines. Clin. Cancer Res. 2009, 15, 2808-2817. [CrossRef]

96. Robak, T.; Robak, E. Current Phase II antibody-drug conjugates for the treatment of lymphoid malignancies. Expert Opin. Investig. Drugs 2014, 23, 911-924.

97. Sherbenou, D.W.; Behrens, C.R.; Su, Y.; Wolf, J.L.; Martin, T.G.; Liu, B. The development of potential antibody-based therapies for myeloma. Blood Rev. 2015, 29, 81-91. [CrossRef]

98. Nittoli, T.; Kelly, M.P.; Delfino, F.; Rudge, J.; Kunz, A.; Markotan, T.; Spink, J.; Chen, Z.; Shan, J.; Navarro, E.; et al. Antibody drug conjugates of cleavable amino-alkyl and aryl maytansinoids. Bioorganic Med. Chem. 2018, 26, 2271-2279. [CrossRef]

99. Waight, A.B.; Bargsten, K.; Doronina, S.; Steinmetz, M.O.; Sussman, D.; Prota, A.E. Structural Basis of Microtubule Destabilization by Potent Auristatin Anti-Mitotics. PLoS ONE 2016, 11, e0160890. [CrossRef]

100. Gébleux, R.; Stringhini, M.; Casanova, R.; Soltermann, A.; Neri, D. Non-internalizing antibody-drug conjugates display potent anti-cancer activity upon proteolytic release of monomethyl auristatin $\mathrm{E}$ in the subendothelial extracellular matrix. Int. J. Cancer 2017, 140, 1670-1679. [CrossRef]

101. Yoshida, S.; Tuscano, E.; Duong, C.; Chung, J.; Li, Y.; Beckett, L.; Tuscano, J.M.; Satake, N. Efficacy of an anti-CD22 antibody-monomethyl auristatin E conjugate in a preclinical xenograft model of precursor B-cell acute lymphoblastic leukemia. Leuk. Lymphoma 2017, 58, 1254-1257. [CrossRef]

102. Peters, C.; Brown, S. Antibody-drug conjugates as novel anti-cancer chemotherapeutics. Biosci. Rep. 2015, 35, e00225. [CrossRef]

103. Jackson, P.J.M.; Kay, S.; Pysz, I.; Thurston, D.E. Use of pyrrolobenzodiazepines and related covalent-binding DNA-interactive molecules as ADC payloads: Is mechanism related to systemic toxicity? Drug Discov. Today Technol. 2018, 30, 71-83. [CrossRef]

104. Trudel, S.; Lendvai, N.; Popat, R.; Voorhees, P.M.; Reeves, B.; Libby, E.N.; Richardson, P.G.; Hoos, A.; Gupta, I.; Bragulat, V.; et al. Antibody-drug conjugate, GSK2857916, in relapsed/refractory multiple myeloma: An update on safety and efficacy from dose expansion phase I study. Blood Cancer J. 2019, 9, 37. [CrossRef]

105. Yong, K.L.; Germaschewski, F.M.; Rodriguez-Justo, M.; Bounds, D.; Lee, L.; Mayes, P.A.; Sully, K.; Seestaller-Wehr, L.M.; Fieles, W.E.; Tunstead, J.R.; et al. Evaluation Of Bcma As a Therapeutic Target In Multiple Myeloma Using An Antibody-Drug Conjugate. Blood 2013, 122, Abstract \#4447 [ASH 2013 55th Meeting].

106. Trudel, S.; Lendvai, N.; Popat, R.; Voorhees, P.M.; Reeves, B.; Libby, E.N.; Richardson, P.G.; Anderson, L.D.; Sutherland, H.J.; Yong, K.; et al. Targeting B-cell maturation antigen with GSK2857916 antibody-drug conjugate in relapsed or refractory multiple myeloma (BMA117159): A dose escalation and expansion phase 1 trial. Lancet Oncol. 2018, 19, 1641-1653. [CrossRef]

107. Jagannath, S.; Heffner, L.T.; Ailawadhi, S.; Munshi, N.C.; Zimmerman, T.M.; Rosenblatt, J.; Lonial, S.; Chanan-Khan, A.; Ruehle, M.; Rharbaoui, F.; et al. Indatuximab Ravtansine (BT062) Monotherapy in Patients With Relapsed and/or Refractory Multiple Myeloma. Clin. Lymphoma Myeloma Leuk. 2019, 19, 372-380. [CrossRef] [PubMed] 
108. Kelly, K.R.; Siegel, D.S.; Chanan-Khan, A.A.; Somlo, G.; Heffner, L.T.; Jagannath, S.; Zimmerman, T.; Munshi, N.C.; Madan, S.; Mohrbacher, A.; et al. Indatuximab Ravtansine (BT062) in Combination with Low-Dose Dexamethasone and Lenalidomide or Pomalidomide: Clinical Activity in Patients with Relapsed / Refractory Multiple Myeloma. Blood 2016, 128, Abstract \#4486 [ASH 2016 58th Meeting].

109. Ailawadhi, S.; Kelly, K.R.; Vescio, R.A.; Jagannath, S.; Wolf, J.; Gharibo, M.; Sher, T.; Bojanini, L.; Kirby, M.; Chanan-Khan, A. A Phase I Study to Assess the Safety and Pharmacokinetics of Single-agent Lorvotuzumab Mertansine (IMGN901) in Patients with Relapsed and/or Refractory CD-56-positive Multiple Myeloma. Clin. Lymphoma Myeloma Leuk. 2019, 19, 29-34. [CrossRef] [PubMed]

110. Stein, R.; Mattes, M.J.; Cardillo, T.M.; Hansen, H.J.; Chang, C.-H.; Burton, J.; Govindan, S.; Goldenberg, D.M. CD74: A New Candidate Target for the Immunotherapy of B-Cell Neoplasms. Clin. Cancer Res. 2007, 13, 5556s-5563s. [CrossRef] [PubMed]

111. Berdeja, J.G.; Hernandez-Ilizaliturri, F.; Chanan-Khan, A.; Patel, M.; Kelly, K.R.; Running, K.L.; Murphy, M.; Guild, R.; Carrigan, C.; Ladd, S.; et al. Phase I Study of Lorvotuzumab Mertansine (LM, IMGN901) in Combination with Lenalidomide (Len) and Dexamethasone (Dex) in Patients with CD56-Positive Relapsed or Relapsed/Refractory Multiple Myeloma (MM). Blood 2012, 120, Abstract \#728 [ASH 2012 54th Meeting].

112. Kaufman, J.L.; Niesvizky, R.; Stadtmauer, E.A.; Chanan-Khan, A.; Siegel, D.; Horne, H.; Wegener, W.A.; Goldenberg, D.M. Phase I, multicentre, dose-escalation trial of monotherapy with milatuzumab (humanized anti-CD74 monoclonal antibody) in relapsed or refractory multiple myeloma. Br. J. Haematol. 2013, 163, 478-486. [CrossRef]

113. Wolf, E.; Hofmeister, R.; Kufer, P.; Schlereth, B.; Baeuerle, P.A. BiTEs: Bispecific antibody constructs with unique anti-tumor activity. Drug Discov. Today 2005, 10, 1237-1244. [CrossRef]

114. Madduri, D.; Dhodapkar, M.V.; Lonial, S.; Jagannath, S.; Cho, H.J. SOHO State of the Art Updates and Next Questions: T-Cell-Directed Immune Therapies for Multiple Myeloma: Chimeric Antigen Receptor-Modified T Cells and Bispecific T-Cell-Engaging Agents. Clin. Lymphoma Myeloma Leuk. 2019, 19, 537-544. [CrossRef]

115. Topp, M.S.; Gökbuget, N.; Stein, A.S.; Zugmaier, G.; O’Brien, S.; Bargou, R.C.; Dombret, H.; Fielding, A.K.; Heffner, L.; Larson, R.A.; et al. Safety and activity of blinatumomab for adult patients with relapsed or refractory B-precursor acute lymphoblastic leukaemia: A multicentre, single-arm, phase 2 study. Lancet Oncol. 2015, 16, 57-66. [CrossRef]

116. Bonello, F.; D'Agostino, M.; Moscvin, M.; Cerrato, C.; Boccadoro, M.; Gay, F. CD38 as an immunotherapeutic target in multiple myeloma. Expert Opin. Biol. Ther. 2018, 18, 1209-1221. [CrossRef] [PubMed]

117. Atamaniuk, J.; Gleiss, A.; Porpaczy, E.; Kainz, B.; Grunt, T.W.; Raderer, M.; Hilgarth, B.; Drach, J.; Ludwig, H.; Gisslinger, H.; et al. Overexpression of G protein-coupled receptor 5D in the bone marrow is associated with poor prognosis in patients with multiple myeloma. Eur. J. Clin. Invest. 2012, 42, 953-960. [CrossRef] [PubMed]

118. Kodama, T.; Kochi, Y.; Nakai, W.; Mizuno, H.; Baba, T.; Habu, K.; Sawada, N.; Tsunoda, H.; Shima, T.; Miyawaki, K.; et al. Anti-GPRC5D/CD3 Bispecific T-Cell-Redirecting Antibody for the Treatment of Multiple Myeloma. Mol. Cancer Ther. 2019, 18, 1555-1564. [CrossRef] [PubMed]

119. Topp, M.S.; Duell, J.; Zugmaier, G.; Attal, M.; Moreau, P.; Langer, C.; Kroenke, J.; Facon, T.; Salnikov, A.; Lesley, R.; et al. Evaluation of AMG 420, an anti-BCMA bispecific T-cell engager (BiTE) immunotherapy, in R/R multiple myeloma (MM) patients: Updated results of a first-in-human (FIH) phase I dose escalation study. J. Clin. Oncol. 2019, 37, Abstract \#8007 [ASCO 2019 Annual Meeting].

120. Cho, S.-F.; Lin, L.; Xing, L.; Liu, J.; Yu, T.; Wen, K.; Hsieh, P.; Munshi, N.; Anderson, K.; Tai, Y.-T. Anti-Bcma BiTE $^{\circledR}$ AMG 701 Potently Induces Specific T Cell Lysis of Human Multiple Myeloma (MM) Cells and Immunomodulation in the Bone Marrow Microenvironment. Blood 2018, 132, Abstract \#592 [ASH 2018 60th Meeting]. [CrossRef]

121. Rasche, L.; Kortüm, K.M.; Raab, M.S.; Weinhold, N. The impact of tumor heterogeneity on diagnostics and novel therapeutic strategies in multiple myeloma. Int. J. Mol. Sci. 2019, 20, 1248. [CrossRef]

122. Nijhof, I.S.; Casneuf, T.; van Velzen, J.; van Kessel, B.; Axel, A.E.; Syed, K.; Groen, R.W.J.; van Duin, M.; Sonneveld, P.; Minnema, M.C.; et al. CD38 expression and complement inhibitors affect response and resistance to daratumumab therapy in myeloma. Blood 2016, 128, 959-970. [CrossRef]

123. Danhof, S.; Strifler, S.; Hose, D.; Kortüm, M.; Bittrich, M.; Hefner, J.; Einsele, H.; Knop, S.; Schreder, M. Clinical and biological characteristics of myeloma patients influence response to elotuzumab combination therapy. J. Cancer Res. Clin. Oncol. 2019, 145, 561-571. [CrossRef] 
124. Ghose, J.; Viola, D.; Terrazas, C.; Caserta, E.; Troadec, E.; Khalife, J.; Gunes, E.G.; Sanchez, J.; McDonald, T.; Marcucci, G.; et al. Daratumumab induces CD38 internalization and impairs myeloma cell adhesion. Oncoimmunology 2018, 7, e1486948. [CrossRef]

125. Moreno, L.; Perez, C.; Zabaleta, A.; Manrique, I.; Alignani, D.; Ajona, D.; Blanco, L.; Lasa, M.; Maiso, P.; Rodriguez, I.; et al. The Mechanism of Action of the Anti-CD38 Monoclonal Antibody Isatuximab in Multiple Myeloma. Clin. Cancer Res. 2019, 25, 3176-3187. [CrossRef] [PubMed]

126. Raab, M.S.; Chatterjee, M.; Goldschmidt, H.; Agis, H.; Blau, I.; Einsele, H.; Engelhardt, M.; Ferstl, B.; Gramatzki, M.; Röllig, C.; et al. A Phase I/IIa Study of the CD38 Antibody MOR202 Alone and in Combination with Pomalidomide or Lenalidomide in Patients with Relapsed or Refractory Multiple Myeloma. Blood 2016, 128, Abstract \#1152 [ASH 2016 58th Meeting].

127. Nijhof, I.S.; Groen, R.W.J.; Lokhorst, H.M.; Van Kessel, B.; Bloem, A.C.; Van Velzen, J.; De Jong-Korlaar, R.; Yuan, H.; Noort, W.A.; Klein, S.K.; et al. Upregulation of CD38 expression on multiple myeloma cells by all-trans retinoic acid improves the efficacy of daratumumab. Leukemia 2015, 29, 2039-2049. [CrossRef] [PubMed]

128. García-Guerrero, E.; Gogishvili, T.; Danhof, S.; Schreder, M.; Pallaud, C.; Pérez-Simón, J.A.; Einsele, H.; Hudecek, M. Panobinostat induces CD38 upregulation and augments the antimyeloma efficacy of daratumumab. Blood 2017, 129, 3386-3388. [CrossRef] [PubMed]

129. Cho, S.-F.; Lin, L.; Xing, L.; Wen, K.; Yu, T.; Hsieh, P.A.; Li, Y.; Munshi, N.C.; Wahl, J.; Matthes, K.; et al. AMG 701 Potently Induces Anti-Multiple Myeloma (MM) Functions of T Cells and IMiDs Further Enhance Its Efficacy to Prevent MM Relapse In Vivo. Abstract \#135, ASH 2019 61st Meeting. Available online: https://ash.confex.com/ash/2019/webprogram/Paper128528.html (accessed on 13 December 2019).

130. Raje, N.; Jakubowiak, A.; Gasparetto, C.; Cornell, R.F.; Krupka, H.I.; Navarro, D.; Forgie, A.J.; Udata, C.; Basu, C.; Chou, J.; et al. Safety, Clinical Activity, Pharmacokinetics, and Pharmacodynamics from a Phase I Study of PF-06863135, a B-Cell Maturation Antigen (BCMA)-CD3 Bispecific Antibody, in Patients with Relapsed/Refractory Multiple Myeloma (RRMM). Abstract \#1869, ASH 2019 61st. Available online: https://ash.confex.com/ash/2019/webprogram/Paper121805.html (accessed on 13 December 2019).

131. Dawicki, W.; Allen, K.J.H.; Jiao, R.; Malo, M.E.; Helal, M.; Berger, M.S.; Ludwig, D.L.; Dadachova, E. Daratumumab-225Actinium conjugate demonstrates greatly enhanced antitumor activity against experimental multiple myeloma tumors. Oncoimmunology 2019, 8, 1607673. [CrossRef]

132. Teiluf, K.; Seidl, C.; Blechert, B.; Gaertner, F.C.; Gilbertz, K.P.; Fernandez, V.; Bassermann, F.; Endell, J.; Boxhammer, R.; Leclair, S.; et al. $\alpha$-radioimmunotherapy with 213Bi-anti-CD38 immunoconjugates is effective in a mouse model of human multiple myeloma. Oncotarget 2015, 6, 4692-4703. [CrossRef]

133. Pandit-Taskar, N. Functional Imaging Methods for Assessment of Minimal Residual Disease in Multiple Myeloma: Current Status and Novel ImmunoPET Based Methods. Semin. Hematol. 2018, 55, 22-32. [CrossRef]

134. Ghai, A.; Maji, D.; Cho, N.; Chanswangphuwana, C.; Rettig, M.; Shen, D.; DiPersio, J.; Akers, W.; Dehdashti, F.; Achilefu, S.; et al. Preclinical development of CD38-Targeted [ 89 Zr]Zr-DFO-Daratumumab for Imaging Multiple Myeloma. J. Nucl. Med. 2018, 59, 216-222. [CrossRef]

135. Caserta, E.; Chea, J.; Minnix, M.; Viola, D.; Vonderfecht, S.; Yazaki, P.; Crow, D.; Khalife, J.; Sanchez, J.F.; Palmer, J.M.; et al. Copper 64-labeled daratumumab as a PET/CT imaging tracer for multiple myeloma. Blood 2018, 131, 741-745. [CrossRef]

136. Ulaner, G.; Sobol, N.; O’Donoghue, J.; Burnazi, E.; Staton, K.; Weber, W.; Lyashchenko, S.; Lewis, J.; Landgren1, C.O. Preclinical development and First-in-human imaging of 89Zr-Daratumumab for CD38 targeted imaging of myeloma. J. Nucl. Med. 2019, 60, Abstract \#203.

(C) 2019 by the authors. Licensee MDPI, Basel, Switzerland. This article is an open access article distributed under the terms and conditions of the Creative Commons Attribution (CC BY) license (http://creativecommons.org/licenses/by/4.0/). 